\title{
"SMALL CLAIMS" CONSUMER PLAINTIFFS IN THE PHILADELPHIA MUNICIPAL COURT: AN EMPIRICAL STUDY
}

\author{
John Montague Steadman $\dagger$ \\ RICHARD S. ROSENSTEIN $\dagger \dagger$
}

\begin{abstract}
Whereas the several laws of this province for determining small debts without formality of trial, were designed for the ease and conveniency of the subject; but complaint is made by many of the inhabitants of the City and County of Philadelphia that the manner of putting the same in execution by some of the said city magistrates and officers, proves very chargeable and inconvenient ....
\end{abstract}

\section{Preamble, Pennsylvania Act of May 28, 1715, Abolishing the Forty- Shillings Court}

Its genesis reaching back deep into Jacobean England, ${ }^{1}$ the "small claims court"2 first flourished in this country in the early part of this century. ${ }^{3}$ It has once again arisen as the subject of scrutiny, as advocates of consumer reform have critically questioned whether the original promise of speedy and inexpensive justice for the poor litigant has not been wildly distorted into a speedy and inexpensive collection

$\dagger$ Professor of Law, Georgetown University Law Center. A.B. 1952, Yale College; LL.B. 1955, Harvard University. Member, California and District of Columbia Bars. The study which this Article represents was made during the spring and summer of 1972, when the first author had the privilege to be a visiting professor of law at the University of Pennsylvania, and the second author a law student there. The study was funded by and made under the auspices of the National Institute for Consumer Justice, a federally sponsored organization located at the University of Michigan Law School in Ann Arbor, Michigan. It was one of several studies of small-claims courts in major metropolitan areas made for the Institute.

†† A.B. 1969, Columbia University; J.D. 1973, University of Pennsylvania.

1 The small claims court movement has been traced back to the statutory creation of a small debt court in London in 1606. Comment, The California Small Claims Court, 52 CALIF. L. REv. 876, 876-77 (1964) [hereinafter cited as Calif. Small Claims Court]; 34 Coludr. L. Rev. 932, 933 n.7 (1934).

2A "small claims court" may generally be defined as a judicial forum in which claims of a small dollar amount may be heard, usually operating with greater speed and informality than the courts of greater jurisdiction.

3 The impetus for the small claims court movement in this country is widely credited to a seminal article by Roscoe Pound, The Administration of Justice in the Modern City, 26 HARv. L. REv. 302 (1913). The first American small claims court was established in Cleveland in that year. In the 25 years thereafter, the bulk of the states created by statute some sort of "small claims court," although their form and nature varied widely. See Comment, Small Claims Court: Reform Revisited, 5 Corum. J.L. \& Soc. ProB., Aug. 1969, at 47-48 \& n.8 [hereinafter cited as Sinall Claims Court Reform]. An extensive bibliography of pre-1940 materials on small claims sourts is contained in Northrup, Small Claims Courts and Conciliation Tribunals, 33 L. LiB. J. 39 (1940). See also INSTITUTE OF Judictal Administration, Smali Cianms Courts in the United States (1955) and SUPPLEMENT (1959). 
mechanism for creditors. ${ }^{4}$ Abuses have been pinpointed, and reforms proposed, to protect the hapless consumer who is swept against his volition into the purview of the small claims court as a defendant. ${ }^{5}$ The purpose of this Article is to examine the issue from another perspective, that of the wronged consumer affirmatively seeking judicial relief, in the context of a specific judicial forum, the Philadelphia Municipal Court, the local "small claims court."

How have consumer plaintiffs fared there? The question bears special interest because the Philadelphia Municipal Court is not a product of the wave of small claims courts established when the movement was at its height in the 1920's and 1930's. ${ }^{6}$ Indeed, until 1969, Philadelphia labored under a magistrate system that was more a product of the 18th century than the 20th. Thus, Philadelphia offers an opportunity to study a court that had half a century of the smallclaims-court experience of other jurisdictions in this country to draw on as well as the history of its predecessor, which was repeatedly criticized as a tool for popular justice.

This paper will outline the history and procedures of the Philadelphia Municipal Court and present the results of an empirical study involving both research into the court records of consumer plaintiff cases and replies to questionnaires sent to such consumer plaintiffs. The basic questions under investigation are the traditional ones used to test the effectiveness of a "small claims" dispute-settlement mechanism, ${ }^{7}$ asked however from the perspective of the consumer plaintiff. Objectively, was the dispute handled quickly and inexpensively, simply and effectively? Subjectively, how satisfied was the consumer

\footnotetext{
4 See, e.g., Wright, The Courts Have Failed the Poor, N.Y. Times, Mar. 9, 1969, § 6 (Magazine), at 26, 102.

5 See Note, The Persecution and Intimidation of the Low-Income Litigant as Performed by the Small Claims Court in California, 21 STaN. L. REv. 1657 (1969) [hereinafter cited as Low-Income Litigant]; Comment, 42 S. CAL. L. Rev. 493 (1969). See also Note, 4 STAN. L. REv. 237 (1952). A well-known consumer magazine recently published an interesting survey of consumer plaintiffs in 4 selected small claims courts, based on court records and questionnaires. The article also contains a summary of basic small claims court procedures throughout the nation. Buyer vs. Seller in Small Claims Court, Consumer RePORTs, Oct. 1971, at 624 [hereinafter cited as Buyer vs. Seller]. In Fox, Small Claims Revisions-A Break for the Layman, 20 DEPaUL. L. Rev. 912 (1971), the author urges a distinction between "collection" cases and cases in which plaintiffs are unrepresented; classification on this basis would constitute a first step toward assuring plaintiffs without counsel a meaningful opportunity to appear in court.

6 See note 3 supra.

7 There is less than total agreement on precisely what the full sweep of the objectives of a "small claims court" should be. For example, is the dollar amount of the claim in dispute the major issue? Is it designed mainly to clear the dockets of the more formal courts? Is it the "poor" who are primarily to be served? Who are the "poor" in this context? Is it to create confidence in the judicial process generally? See, e.g., Low-Income Litigant, supra note 5, at 1657-59; Calif. Small Claims Court, supra note 1, at 876-77.
} 
with the process, that is, not whether he won or lost, but whether he derived a sense of justice truly done, fairly and courteously? ${ }^{8}$

\section{Philadelphia Municipal Court: The Product of Reform}

The Philadelphia Municipal Court is of extremely recent origin, only beginning operation in $1969 . .^{\circ}$ An understanding of the establishment of this new court and of its predecessor, the magistrate system, ${ }^{10}$ is essential to any analysis of the present structure and functioning of the court. This is especially true because of the apparently conscious effort on the part of both its designers and present administrators to overcome perceived injustices of the past.

\section{A. Historical Background}

Prior to 1969 , the magistrates' courts of Philadelphia were the lowest forum for civil litigation, up to a statutory limit of $\$ 100 .^{11}$ The

8 This study confines itself to the Philadelphia Municipal Court as one specific mechanism for the resolution of small claims. Small claims courts have also come under scrutiny in the larger context of examining the whole range of alternative mechanisms for resolving consumer disputes. See, e.g., Eovaldi \& Gestrin, Justice for Consumers: The Mechanisms of Redress, 66 Nw. U. L. REv. 281 (1971) (an excellent recent article); Special Committee on Consumer Affairs, Ass'n of the Bar of the City of New York, Toward the Informal Resolution of Consumer Disputes, 27 REcoRo of THE N.Y.C.B.A. 419 (1972); Note, Consumer Protection in Pennsylvania, 30 U. PrTr. L. Rev. 113 (1968); Note, Translating Sympathy for Deceived Consumers into Effective Programs for Protection, 114 U. PA. L. REv. 395 (1966).

9 The new judicial article to the Pennsylvania Constitution establishing the Philadelphia Municipal Court was approved by the electorate on April 23, 1968, to become effective on January 1, 1969. Although enabling legislation was not enacted by the Pennsylvania legislature until October 17,1969 , the provisions of the constitutional amendment and attached schedule were sufficiently detailed to permit the court to begin operation at the beginning of the year. The present salaries of the judges are $\$ 21,000$ for the president judge, $\$ 20,000$ for each attorney judge (the "Law Judges") and $\$ 16,500$ for the nonattorney judges (the "Lay Judges"), PA. Star. ANN. tit. 17 \& 711.2 (Supp. 1973). Twenty-two judges are authorized for the court, id. \& 711.1. Eight of these at present are attorneys.

${ }^{10}$ Although there are significant differences in jurisdiction, the municipal court is generally thought of as the successor to the old magistrates' courts. This is in part because both are the lowest court in the hierarchy, but also because by the terms of the 1968 constitutional amendment establishing the municipal court, all but 6 of the then sitting magistrates automatically became judges of the new municipal court. PA: ConSt. art. 5, \& 16(e) (Sched.).

11 PA. Const. art. 5, § 12 (1909). General civil jurisdiction was vested in a constitutional court of common pleas, PA. Const. art. $5, \S 6$ (1911), and in a statutory Philadelphia county court, which had concurrent civil jurisdiction up to $\$ 5,000$. PA. STAT. ANN. tit. 17, $\S 693$ (1962). Actions involving $\$ 100$ or less could be brought only in the county court or a magistrate's court. The county court came into existence in 1913 under the name of the Municipal Court of Philadelphia and was redesignated as the County Court of Philadelphia in 1961, to prevent confusion with the lowest courts of other states. Id. \& 705. The judges then sitting on the Philadelphia County Court automatically became members of the family court division of the court of common pleas upon the adoption of the 1968 amendment to the Pennsylvania Constitution which abolished the county court. PA. Const. art. 5, \$16(c) (Sched.). Thus, care should be taken not to confuse references to the "Philadelphia Municipal Court" in writings prior to 1961 with the Philadelphia Municipal Court established in 1968 and discussed in this study. Also, it should be noted that historically the court structure of the City of Philadelphia has differed markedly from that of the rest of the Commonwealth. For example, only Philadelphia has a "municipal court." 
courts were not of record,,$^{12}$ the filing fee was only $\$ 2.50-\$ 5.00,{ }^{13}$ and there was no requirement that a magistrate be a member of the bar. ${ }^{14}$ As constitutionally required, Philadelphia was divided into some twenty-eight districts, in each of which a separate magistrate's court was established. ${ }^{15}$ Magistrates were elected on the general ballot every six years ${ }^{16}$ and received preference in district selection by lot. ${ }^{1 \tau}$ Each magistrate also had the power to select up to three constables from the pool of constables voted into office. ${ }^{18}$ They were forbidden from having any career other than that of magistrate while serving, ${ }^{19}$ and received a salary of $\$ 12,500$ per year. ${ }^{20}$

On the surface, then, the fact that magistrates served in a number of courts located throughout the city, and conducted informal proceedings for a small fee, would seem to conform with a number of the ideals of the small claims movement. In reality, however, the magistrate system seems to have been widely perceived as a corrupt, inefficient and unfair forum in which fair and honest rendering of justice could not be relied on. ${ }^{21}$

Public contempt for the minor judiciary in Philadelphia was not without precedent. As far back as 1715 , the system in Philadelphia, known as the "Forty-Shillings or Two Weeks Court," had already fallen into disrepute, and jurisdiction was given to the Justice of the

12 PA. Const. art. 4, § 12 (1909):

13 Pa. Stat. ANn. tit. 42, § 233 (1966).

14 The only qualifications for the office were that a candidate must be at least 35 years old, have resided in Philadelphia continuously for 5 years prior to the election, be a native-born or naturalized citizen for at least 10 years, and be a qualified voter. Id. § 1048. The first requirement was upheld against a charge of being arbitrary and capricious in Commonwealth ex rel. Kelley v. Kaiser, $340 \mathrm{~Pa}$. 59, 16 A.2d 307 (1940).

15 PA. Const. art. 5, \& 12 (1909). In a reform attempt apparently designed to establish an effective small claims court for Philadelphia, the legislature in 1937 provided that all civil cases should be heard by 3 magistrates sitting en banc in City Hall. The provision was struck down as violative of the constitutional requirement that the magistrates' courts constitute "a basic structure of subordinate tribunals to be located throughout the city." Rutenberg v. Philadelphia, 329 Pa. 26, 37, 196 A. 73, 78 (1938). This case contains an excellent summary of the structure and nature of the magistrates' courts. A more extensive description of the magistrates' courts may be found in S. ScHULMaN, Toward Judicial Reform in Pennsylvania (1962).

16 PA. Const. art. 5, § 12 (1909).

17 Pa. STat. AnN. tit. 42, § 1050 (1966).

$18 \mathrm{Id}$. \& 1062.

19 Id. \& 1103.

20 Id. § 1138.

21 See notes 22-51 infra \& accompanying text. In fact, the old Municipal Court of Philadelphia, note 11 supra, served as the focus for early attempts to carry out the aims of the small claims movement. In 1915, Judge Wheeler of that court made a special survey and report, and in 1920 a "Conciliation, Small Claims and Legal Aid Division" of the court was established. Four years later a "Poor Man's Court" was established to hear cases originated by Philadelphia's Bureau of Legal Aid. However, the Poor Man's Court was not successful because it had no compulsory jurisdiction, and submission to arbitration was voluntary. S. ScHuLMaN, supra note 15, at 117; cf. Stewart \& Abrahams, A Small Claims Court for Pennsylvania, 85 U. PA. L. REv. 15 (1936) (commenting on the magistrates' courts). 
Peace.22 Likewise at the Constitutional Convention of 1872-1873, which abolished the position of alderman and substituted the magistrate system, complaint was made that

[e]verything conspires ... to place [in the office of alderman] venal, brutal and unprincipled men, whose sole object is to extract the largest possible amount of gain from the position and who have little scruple how that gain is attained. To such men is confided power almost despotic and irresponsible over the poor, the friendless, the helpless. ${ }^{23}$

As had been their predecessors, the Philadelphia magistrate's courts were a source of controversy and periodic investigation. In 1935, twenty-seven of twenty-eight magistrates were indicted by a grand jury, the major complaints being in the area of criminal justice. ${ }^{24}$ In 1948 the Chief Magistrate was indicted and was acquitted after a second trial. ${ }^{25}$

A 1937 reform act tried to take civil jurisdiction out of the hands of the entire magistrate system and put it in the hands of three magistrates sitting at one central location. ${ }^{26}$ This was struck down by the Pennsylvania Supreme Court as contrary to the state constitutional scheme. ${ }^{27}$

In the late 1950's a joint study by the Bureau of Municipal Research and the Philadelphia Economy League found the magistrate system to be deficient. ${ }^{28}$ The BMR-PEL report criticized the cramped quarters and lack of decorum in the court. ${ }^{29}$ They found instances of magistrates starting much later than the scheduled time, noise and confusion during hearings, rudeness on the part of magistrates to witnesses and spectators, people talking privately to magistrates while court was in session, and even found instances in which two separate magistrates solicited votes during a hearing. ${ }^{30}$

- Finally in 1964 the Attorney General's Office of the Common-

22 Act of May 28, 1715, quoted in S. SchulMaAN, supra note 15, at 103 n.38, the preamble to which is set forth at the head of this Article.

234 Debates, Constitutionai Convention of 1873, at 274, quoted in S. SchulMLAN, supra note 15 , at 104.

24 Bureau of Municipal Research \& Pennsyuvanta Economy Ieague, The Magistrates' Courts of PhILADELPHIA 11 (1958).

25 Id. 17.

26 Magistrates Court Act of 1937, Pub. L. No. 1743.

27 Rutenberg v. Philadelphia, 329 Pa. 26, 196 A. 73 (1938). See note 15 supro.

28 Bureat of Muntcipal Research \& Pennsylvania Economy league, The Magistrates' Courts of PhIladelphia (rev. ed. 1958). The tone of the report is notably negative concerning the conduct of the court and the lack of proper record keeping.

29 Id. 69.

30 Id. 70. In addition the report points out that in discussions with attorneys and from a brief survey of the record it seemed that defendants never won civil cases and in fact $90 \%$ of all cases ended in default judgment for the plaintiff. 
wealth launched a full scale investigation of the magistrate system. ${ }^{31}$ On the merits of the civil side of the magistrates' courts, the report concluded:

Among Philadelphians who do not know the "judge", a general feeling prevails that they cannot obtain justice in the magistrates' courts. Even those with means to afford an attorney to represent their interests do not bother to do so because they know that attendance at a magistrate's hearing will be a waste of time since no reasonable person can have any doubt as to the magistrate's decision. ${ }^{32}$

The investigators discovered that many magistrates did not know that their jurisdiction was limited to $\$ 100$, and some thought it was almost twice as much. Cases were found in which judgments were handed down up to $\$ 300$ and as high as $\$ 724 .^{33}$

The probe also revealed that many constables owned collection agencies ${ }^{34}$ and through the '50's had advertised magistrate connections as part of their services. ${ }^{35}$ Constables were found to have taken fees between $25 \%$ and $50 \%$ of the debt for their services. ${ }^{36}$ One magistrate admitted that his wife had a one-half interest in one of these constable collection agencies. ${ }^{37}$

Magistrates engaged in extrastatutorial activities to aid the collection process. Some wrote dunning letters to debtors indicating that legal action might be taken against the debtor. ${ }^{38}$ It was also found that criminal process was being used to intimidate debtors into meeting installment payments. ${ }^{39}$ Some magistrates issued notices that the magistrate had a warrant for the debtor's arrest on the charge of "Civil Debt." 40 Other magistrates issued warrants on constable complaints against debtors for fraudulent conversion or larceny by bailee. ${ }^{41}$ If

31 Commonwealth of Pennsylvanta, Dep't of Justice, Report of the Attorney General on the Investigation of THE Magisterial System (1965) [hereinafter cited as REP. OF AtTORNey General]. The first staff appointments were made on October 6, 1964, and the final report completed on April 30, 1965.

32 Id. 29.

33 Id. 26.

34 Id. 27.

35 Id. In many cases it was found that magistrates and constables worked closely together and may have even shared the same offices.

${ }^{36} I d$. 26-27. It was noted that this interest gave an added zeal to the constables' efforts to collect.

37 Id. 28. This same magistrate, when asked why he handled the number of cases he did, answered: "I handle all this business for one reason. If my wife makes money, I'm going to benefit by it because I have an opportunity to spend some of the money she makes, being the president of the company that employs the Constable who handles the work." Id.

38 Id. 28-29.

39 Id. 29.

$40 I d$.

41 Id. 
the summons did not bring results the debtor would be taken before the magistrate. ${ }^{42}$ In some cases debtors were arrested, photographed, fingerprinted and released on bail. ${ }^{43}$ These cases resulted in payment and never were brought to trial. There was even found one case in which the charge was "Breach of Contract." 44

Even when measures as drastic as arrest or magistrate dunning letters were not used the investigation found justice very uneven in the magistrates' courts. Cases were decided without proof of service of process and even decided in some cases in which the constable had affirmatively stated that they had not served the defendant. ${ }^{45}$ Constables sometimes stood in for plaintiffs at hearings. ${ }^{46}$ There was excessive abuse by constables in imposing of costs. ${ }^{47}$ What compounded all this was the very poor recordkeeping on the part of the magistrates' courts. $^{48}$

It took a constitutional convention to change the magistrate system. Two major proposals suggested the abolition of all minor courts and their replacement with community courts. ${ }^{49} \mathrm{~A}$ third proposal suggested retention but drastic reform of the magistrate system of Philadelphia. ${ }^{50}$ Some suggested only reform in Philadelphia, others pushed. for uniform change. ${ }^{51}$

The final proposal approved by the convention, which was recommended to and approved by the voters in 1968, abolished the magistrate system and provided for the new Philadelphia Municipal Court. ${ }^{52}$ The Schedule to the proposal stipulated that all sitting magistrates would be retained, but nonlawyer magistrates could be elected for only one more six-year term past their present one. ${ }^{53}$ It also gave the president judge of the court of common pleas extensive supervisory

$42 I d$.

43 Id.

44 Id. 30.

45 Id. 30 .

46 Id. 31.

${ }^{47}$ Id. Magistrates took little interest in this practice. There was also widespread use of execution procedures, especially levies, to harrass debtors into paying.

48 Id. 32. The investigation found that the records frequently did not show plaintiff's claim, whether valid service had been made, who was present at the hearing, what testimony was presented, whether execution issued, whether levy was made or if the judgment was satisfied. It is true, however, that the magistrates' courts were constitutionally not courts "of record." PA. Const. art. 4, \$12 (1909).

49 Pennsylvania Bar Association Proposed Judiciary Article \& 5 (1964), reproduced in Preparatory Committee, Pennsylvania Constitutional Convention of 1967-68, Reference Manual No. 5, at 382 (1967); Report of the Governor's Conacrission on Constitutional ReVtsion art. 5, § 5, at 32-33 (1964).

50 Report of the Comantssion on Constitutional Revision art. 5, § 12, at 31-32 (1959) [hereinafter cited as WoodsIoE Comarrssion].

51 Id. 1274-77 \& submissions cited.

52 Id. 1415 (Proposal No. 7, §6(c)). This proposal is now PA. Const. art. 5, § 6(c).

53 Pa. Const. art. 5 , § 16(v) (Sched.). 
power and the right to appoint the president judge of the municipal court until all the judges of that court were attorneys. ${ }^{54}$ It expanded the jurisdiction over civil cases up to $\$ 500,{ }^{55}$ but limited the hearing of civil cases to the attorney judges. ${ }^{56}$ Thus today, all civil matters come before the (presently) eight attorney members of the municipal court, whose number is supplemented from time to time by judges of the common pleas court assigned temporarily to municipal court duty. Only one or two judges are engaged each day in hearing civil matters; typically each attorney judge of the court will serve for a week at a time in that capacity.

On October 17, 1969, over nine months after the new municipal court began operation under the new constitution, the state legislature finally passed enabling legislation. ${ }^{57}$ There were several important changes made from the bill as originally introduced, including the granting to the president judge of the municipal court of the power to appoint writ servers ${ }^{58}$ and the allowance of a $\$ 5$ writ service fee. ${ }^{59}$ Among the controversial sections of the original bill were those allowing only the attorney judges to prescribe the procedural rules of the court $^{60}$ and providing for a pay differential between the attorney judges and the nonattorney judges. ${ }^{61}$ One proposed amendment that was not enacted would have allowed a person to go forward in forma

$54 I d . \S 16(\mathrm{~h})$.

55 Id. $\S 16(\mathrm{r})(\mathrm{v})$. Technically the limit is $\$ 499.99$, as jurisdiction exists over civil claims "less than five hundred dollars."

56 Id. \& $16(\mathrm{r})$. This limitation does not apply to "[m]atters arising under The Landlord and Tenant Act of 1951." Id. § 16(r) (iv).

57 Pa. Stat. ANN. tit. 17, §§ 711.1-.27 (Supp. 1973). The bill was introduced Feb. 4, 1969, H. 128, 1969 Pa. Legis. Sess. (Printer's No. 150), by Representatives Fineman and Coppolino and signed into law on Oct. 17, 1969, by then-Governor Schaefer.

58 This addition was made by the House on June 16, 1969, H. 128, $1969 \mathrm{~Pa}$. Legis. Sess., $\$ 27$ (Printer's No. 1578) (codified at PA. Stat. Ann. tit. 17, § 711.27. (Supp. 1973)).

59 This provision was first added by the House on Apr. 28, 1969, H. 128, $1969 \mathrm{~Pa}$ Legis. Sess., \& 9(c) (Printer's No. 1190) (codified at PA. STaT. ANN. tit. 17, \& 711.9(c) (Supp. 1973)).

60 This provision was in the original bill, H. 128, 1969 Pa. Legis. Sess. (Printer's No. 150), but was eliminated in the Senate Judiciary Committee, July 22, 1969, H. 128, 1969 $\mathrm{Pa}$. Legis. Sess. (Printer's No. 1926). It was reinstated in the final version, as re-reported from the Senate Appropriations Committee, Sept. 9, 1969, H. 128, 1969 Pa. Legis. Sess. (Printer's No. 2005) (codified at Pa. Stat. ANw. tit. 17, \& 711.6 (Supp. 1973)).

61 This provision had a turbulent history. It appeared in the original bill, H. 128, $1969 \mathrm{~Pa}$. Legis. Sess., § 2 (Printer's No. 150). The differential in pay was eliminated in the amended House version of Apr. 28, 1969, H. 128, 1969 Pa. Legis. Sess., \& 2 (Printer's No. 1190). It was reinstated in the amended House version of June 16, 1969, H. 128, $1969 \mathrm{~Pa}$. Legis. Sess., \& 2 (Printer's No. 1578). Struck again in the amended version presented by the Senate Judiciary Committee on July 22, 1969, H. 128, $1969 \mathrm{~Pa}$. Legis. Sess., $\S 2$ (Printer's No. 1926), it was reinstated for a second time in the final version re-reported by the Senate Appropriations Committee on Sept. 9, 1969, H. 128, $1969 \mathrm{~Pa}$. Legis. Sess., § 2 (Printer's No. 2005). This version was signed into law and with it the difference in pay between lawyer and nonlawyer judges. PA. STAT. ANN. tit. 17, \& 711.2 (Supp. 1973). See note 9 supra. 
pauperis after paying a $\$ 1$ fee in lieu of all other fees. ${ }^{62}$ This was dropped in favor of a clause which allows the court to waive fees at its discretion. ${ }^{63}$

\section{B. Structure and Civil Procedures ${ }^{64}$}

The present court structure and procedures thus reflect a serious attempt to respond to the problems of the old magistrate system, ${ }^{65}$ but hammered out in the political arena where several conflicting forces were at work. Compromises were made, but all in all, procedures in the new court seem to reflect a felt necessity to upgrade its role and safeguard its integrity by providing for a certain formality, care, adhesion to the substantive law, keeping of records, and the like. At the same time, the procedures do show a due recognition of the "small claims" character of the court. ${ }^{60}$

\section{Filing the Claim}

Unlike some small claims courts, ${ }^{67}$ the Philadelphia Municipal Court permits attorneys at all stages, and is open to both corporate

62 The original bill contained no provision for waiver of fees, H. 128, $1969 \mathrm{~Pa}$. Legis. Sess. (Printer's No. 150). This scheme was introduced in the amendments in the House on Apr. 28, 1969, H. 128, 1969 Pa. Legis. Sess., \& 10 (Printer's No. 1190). It was altered to the language in the bill as finally passed in amendments in the House on June 16, 1969, H. 128, 1969 Pa. Legis. Sess., \& 10 (Printer's No. 1578).

63 Amendments in the House on June 16, 1969, H. 128, 1969 Pa. Legis. Sess., \& 10 (Printer's No. 1578). The present law provides that " $[t]$ he court, upon cause shown, may in a proper case waive payment of filing fees for the commencement of the action or other costs." Pa. StaT. ANN. tit. 17, \& 711.10 (Supp. 1973). It was learned from discussions with court personnel that the filing fee is automatically waived for those on public assistance and that other cases must be presented to one of the judges.

64 The following description of the practices and procedures of the Philadelphia Municipal Court is based upon the statutes and rules, upon personal observations in the courtrooms and offices, and upon conversations with several of the sitting judges and court personnel.

65 For further information on the creation of the new court structure, see Amram \& Schulman, Constitutional Revision-Further Implementation, 42 PA. B. Ass'N O. 9 (1970) ; Comisky \& Edwards, Pennsylvania's New Judiciary Article, 40 PA. B. Ass'N Q. 567 (1969); Comisky \& Kerstal, Analysis of New Judiciary Article, 40 PA. B. Ass'N Q. 68 (1968).

66 The drafters of the 1968 amendment to the constitution clearly had in mind that the new court was to deal with small claims. Thus, in the new judicial article, it was provided that no right to trial by jury would exist in civil cases in the municipal court, "it being the purpose of this subsection to establish an expeditious small claims procedure whereby it shall not be necessary for the litigants to obtain counsel." PA. Const. art. 5, $\S 16(r)$ (v) (Sched.). Indeed, the handbook of the court itself designates the nature of its general civil jurisdiction as "Small Claims." HANDBOOR OF TEE PHILADELPHIA MUNICIPAL CouRT 3 (1971) [hereinafter cited as HaNDBook].

67 Wide variation exists among the states both with regard to who may bring suit as party plaintiff and whether and the extent to which attorneys may participate. For example, California, unlike Pennsylvania, bars all attorneys other than directors or officers appearing as representatives of a corporate party, but is in accord with Pennsylvania in permitting corporations to be plaintiffs. CaI. CIV. Pro. Code $\$ 117(\mathrm{~g})$ (West 1954). This exclusion of attorneys was held to be constitutional in Prudential Ins. Co. v. Small Claims Court, 76 Cal. App. 2d 379, 173 P.2d 38 (1946); on the constitutionality of barring attorneys, see Annot., 167 A.I.R. 820 (1947). Although it does not bar representation by attorneys, New York differs from both California and Pennsylvania in forbidding 
and individual plaintiffs. ${ }^{68}$ Corporations must be represented by attorneys. ${ }^{69}$ Civil claims can only be in assumpsit or trespass, ${ }^{70}$ with a jurisdictional limit of $\$ 500 .^{71}$ No equity powers are vested in the court; landlord-tenant disputes involving rent collections or eviction proceedings are handled under a separate grant of jurisdiction. ${ }^{2}$ Although no specific venue provisions exist, by rule of court a defendant may only be served within the City of Philadelphia. ${ }^{73}$ The only exception is found in a special provision authorizing, upon petition to the court, service on a corporation by registered mail or publication. ${ }^{74}$

The consumer plaintiff commences an action by filing a sworn "Statement of Claim" with the clerk of the court. The form is provided by the clerk's office and is designed to be simple and informal. ${ }^{75}$ Furthermore, the clerk's office provides significant assistance to the layman in filling out the form.

Located on the second floor of Philadelphia's City Hall in the heart of the city, this office is open during the normal weekday hours of nine to five. Although it is not identified as the "small claims

the appearance of all corporations as plaintiffs with an exception for "municipal corporation[s], public benefit corporation[s] or school district[s] wholly within the municipal corporate limit." N.Y.C. CIVII CT. Acr § 1809 (McKinney Supp. 1972). Buyer vs. Seller, supra note 5 , contains a table generally summarizing small claims court procedures in each of the states, but cautions that "rules and procedures from court to court within a state can be highly individualistic." Id. 628.

68 No restrictions exist either in the statutes or in the court rules on mass filings by plaintiffs or the number of times a plaintiff may appear over the year. Class actions would technically appear permissible. Provision is made in the rules of court for joinder and interpleader. PmIIA. MUN. CT. R. Civ. P. 111, 112.

69 HANDBOOK, supra note 66 , at 3 .

70 Constitutionally the jurisdiction of the Philadelphia Municipal Court is without restriction, that is, shall be "as provided by law." PA. CONST. art. 5, $\S 6$ (c). Initially the new court was given jurisdiction over "[a]1l civil claims involving less than five hundred dollars." PA. CoNst. art. 5, \& 16(r) (v) (Sched.). However, the 1969 enabling statute limited the civil jurisdiction of the court to "civil claims in trespass and assumpsit," but with the stipulation that "[j] urisdiction over civil claims in trespass shall extend to all forms of trespass." PA. STAT. ANN. tit. 17, § 711.3 (Supp. 1973). Generally, small claims courts' jurisdiction over civil cases is limited to tort and contract. Libel and slander are often excluded; assault and battery and malicious prosecution are excluded less frequently. See Small Claims Court Reform, supra note 3, at 60.

71 Pa. Stat. AnN. tit. 17, $\$ 711.3$ (Supp. 1973). This amount is exclusive of interest and costs. Pruta. Mun. CT. R. Civ. P. 101.

72 The court is given jurisdiction over "[m]atters arising under The Landlord and Tenant Act of 1951." PA. Const. art. 5, \& 16(r) (iv) (Sched.). Unlike other civil actions, these cases do not have to be heard by the attorney judges of the court. However, in practice all landlord-tenant cases are heard at the same time and by the same judge as all other civil claims.

73 Phita. Mun. Ct. R. Civ. P. 103.

74 Id. 107(c); PA. R. Crv. P. 2180(c). The limitation of actions to defendants who may be served within Philadelphia is a significant protection to consumer defendants. Other states have found serious abuses in this regard where corporate creditors are allowed by venue provisions to sue distant debtors. See, e.g., Low-Income Litigant, supra note 5 , at 1671-72.

i5 See PeIL. Mun. Ct. R. Civ. P. 105. 
court" nor particularly well marked by signs, personnel in the building readily direct an individual to the proper room. ${ }^{76}$ The office itself contains several rows of benches for prospective plaintiffs to occupy while waiting to be called by a clerk in the other half of the room. The clerks estimate the range of waiting time from none at all up to fortyfive minutes; the questionnaires indicate that a significant number of plaintiffs recall the wait as considerably longer. ${ }^{77}$

The clerk fills out the complaint in the proper form after determining the details of the dispute by interviewing the plaintiff. The clerks said they were prepared to take as long as forty minutes with a plaintiff to understand the situation and complete the forms; the questionnaires confirm considerable satisfaction with their assistance. ${ }^{78}$ The handwritten data is then typed up on the Statement of Claim by a typist in the clerk's office. An important step is the photocopying of appropriate documentary evidence, such as the contract, and attachment to the complaint. ${ }^{79}$ This also is done within City Hall. At the time the complaint is filed, a hearing date is set, which the rules provide will be not more than sixty days in the future. ${ }^{80}$ The plaintiff thus knows, when he leaves the clerk's office, exactly when to reappear for the trial.

The clerk's office also undertakes to arrange for service on the defendant. The statute permits the municipal court to provide for service of process by certified mail return receipt requested, by personal service or by "any other method approved by leave of court." 181 fact, the rules of the court require personal service to be attempted by

76 In this regard, it might be noted that this study,. focusing on actual consumer plaintiffs, does not directly explore the nature or extent of aggrieved consumers who did not use the municipal court, and the reasons why not. As later described, the study did reveal that prior to the filing of a claim, consumers seem to have no clear focus on any other single governmental agency to which to turn. The group here studied is clearly a highly motivated group. It is no simple matter even to seek out and find the municipal court clerk's office within the city hall, perhaps traveling many miles to do so, much less to stick with the case through the trial itself. The writers' subjective reaction was not so much surprise at how few did this, but how many, even within the fourth largest city in the country.

77 Twenty-three percent of the plaintiffs recalled waiting more than an hour to complete the filing of their claims. Appendix B, Table S-1, infra; see text accompanying note 201 infra.

78 See text following note 201 infra.

70 Where the claim is based upon a written contract, 3 copies of at least the pertinent portions must be filed with the Statement of Claim. However, if the contract is not available, it is sufficient simply to explain why and describe its provisions. Pren. MUN. Cr. R. Crv. P. 105(e). In cases involving personal injury or property damage, a sworn affidavit by doctors, repairmen or others providing curative or repair services is normally attached as an exhibit to the Statement of Claim, to provide expert evidence of damages. This permits entry of default if the defendant does not appear, Id. 114(c), and simplifies proof in any event.

$80 I d$. 106. In fact, the date set is sometimes longer. See text accompanying notes 139-40 infra; Appendix B, Table E-1, infra.

81 Pa. Stat. AnN. tit. 17, § 711.7(1)-(3) (Supp. 1973). 
municipal court writ servers in the first instance. ${ }^{82}$ Only if such personal service cannot be effected may certified mail be used. ${ }^{83}$ The writ servers are appointed by the president judge and serve at his pleasure. ${ }^{84}$ Most of such servers are said to be ex-constables. ${ }^{85}$ Service may be made by serving the defendant personally or by leaving the writ with a responsible adult at the defendant's home or place of business. ${ }^{86}$ After service, the writ server fills out an affidavit, detachable from the writ, swearing that service has been made.

Although the plaintiff is thus considerably assisted in getting the claim filed and process served, the cost is not inexpensive by normal small claims court standards. ${ }^{87}$ The filing fee is statutorily set at $\$ 6^{88}$ and by rule of court an additional $\$ 1$ for each additional defendant. ${ }^{89}$ The fee for service of process is $\$ 5$ for each defendant (except where the defendants may be served at the same address). ${ }^{90}$ The statute provides that these fees may be waived by the court upon cause shown in a proper case. ${ }^{91}$ It appears that fees are rarely waived except in welfare cases.92 If the plaintiff prevails, the award of costs is at the discretion of the court; ${ }^{93}$ the records make the nature of the exercise of this discretion less than clear. ${ }^{94}$

82 Pinta. Mun. Cr. R. Civ. P. 107(a).

83 Parta. Mon. Cr. R. Crv. P. 107(b). Registered mail service has reportedly met with a record of success in other jurisdictions, see Comment, supra note 3 , at 52, and . has been sustained as constitutional, Wise v. Herzog, 114 F.2d 486 (D.C. Cir. 1940).

83 Id. 107(b). Registered mail service has reportedly met with a record of success in other jurisdictions, see Small Claims Court Reform, supra note 3, at 52, and has been sustained as constitutional, Wise v. Herzog, 114 F.2d 486 (D.C. Cir. 1940). Although it is perhaps somewhat less certain, its advocates note the lower cost and the protection afforded defendants against so-called "sewer service." See Comment, Abuse of Process: Sewer Service, 3 Colum. J.L. \& Soc. Prob. 17 (1967). Sewer service is not known to be a problem in Philadelphia.

84 Pa. Stat. ANn. tit. $17 \S 711.27$ (Supp. 1973). For a history of this provision, see note 58 supra.

85 Interview with court personnel.

86 PhIIA. Mun. Ct. R. Civ. P. 107 (c); Pa. R. Crv. P. 1009. Service upon corporations, partnerships and unincorporated associations is provided for by separate sections. See PHIIA. Mun. CT. R. Civ. P. 107(c) \& rules cited. As mentioned, generally service must be made within Philadelphia. See notes 73-74 supra \& accompanying text.

87 See Small Claims Court Reform, supra note 3, at 51-52. The difficulty is to balance the desire for a low fee in appropriate cases with the desire to avoid a nearly free collection service for creditors. Id. See also Buyer vs. Seller, supra note 5.

88 Pa. Stat. Ann. tit. 17, \& 711.9(a) (Supp. 1973).

89 Prina. Mun. Ct. R. Civ. P. 102. 107 (a)

90 Pa. Stat. Ann. tit. 17, § 711.9(c) (Supp. 1973); Phila. Mun. CT. R. Civ. P.

91 Pa. Stat. Ann. tit. 17, $\$ 711.10$ (Supp. 1973).

92 See note 63 supra.

93 Pa. Stat. AnN. tit. 17, § 711.21 (Supp. 1973).

$94 \mathrm{By}$ the court-prescribed form of Statement of Claim, the plaintiff automatically asks for his costs. However, the portion of the form in which the judge writes the disposition of the case has no separate entry for costs. The responses to the questionnaires indicated that costs were awarded to the plaintiff in only 33 cases of the 179 answering, and suggested an uncertainty about the whole point. The matter of costs seemed rarely to be raised in court sessions attended. 
The defendant, once served, has several options. First, he can just appear on the hearing date and defend his position. As in the majority of small clains jurisdictions, ${ }^{95}$ the defendant is not required to respond to the complaint prior to the hearing. Indeed, no answer, objection, motion or even counterclaim of any kind may be made by the defendant until the time of the hearing. ${ }^{96}$ Second, if the date is inconvenient for any good reason he may ask for a continuance in writing or have his attorney ask for a continuance on the hearing date before the judge. ${ }^{97}$ Third, he always has the option of not appearing and having a default judgment entered. ${ }^{98}$ Fourth, he may settle the case out of court. Fifth, if he has a counterclaim he may present it at the hearing. ${ }^{99}$ The claim and counterclaim will be heard at the same time unless the defendant is asking more than $\$ 500.00$ in the counterclaim. In that event, the matter is continued so that he may commence an action on the counterclaim in the court of common pleas. ${ }^{100}$ If he does not so file within thirty days, the municipal court may decide the case before it without regard to the alleged counterclaim. ${ }^{101}$ No arbitration or conciliation procedures are provided for in municipal court actions.

\section{The Trial}

Contrary to the old system where the various magistrate courts were located throughout the city, all civil hearings of the Philadelphia Municipal Court are held in the City Hall beginning daily at 3:45 p.m. and continuing as long as necessary, tọ as late as 7:30 or 8:00.102 While not required by statute, the decision to centralize court operations is said to have been predicated upon carefully weighing the pros and cons. ${ }^{103}$ Either one or two courtrooms are used, depending upon the number of cases and the time of year.

All parties are required to be present at the opening of court. The clerk calls the roll of cases scheduled from a computer printout. While this is being done another clerk sorts copies of the Statements

05 See Calif. Small Claims Court, supra note 1, at 880.

96 Penta. Mun. CT. R. Civ. P. 109.

97 Id. 113 (c).

98 Although judgment by confession is legal in Pennsylvania, at least in some circumstances, Swarb v. Lenox, 405 U.S. 191 (1972), this much criticized practice is not permitted in the municipal court. Prma. MUN. Cr. R. Crv. P. 116(a): To some degree this must inhibit the court's use by creditors as a judicial collection mechanism.

99 Prina. MUn. Cr. R. Crv. P. 110(a).

100 Id. 110 (b).

$101 \mathrm{Id}$. Of the 614 consumer plaintiff cases studied, almost none showed that a counterclaim had been raised.

102 In rare instances a court session will continue after 8 o'clock. One of the judges interviewed said that if a case looks as if it may last a good while, he will continue it and hear it the next morning if he is sitting in criminal session.

103 Comisky \& Edwards, supra note 68 , at 571. 
of Claim into separate groups according to the response of the roll call. Attorneys are instructed to answer for their client.

At this point, the robed judge enters from the back of the bench. All attorneys are seated either in chairs or in the jury box inside the bar. Everyone else-parties, witnesses and spectators-is seated in several rows of chairs behind the bar. There is a court reporter present and assorted court officers. There is no smoking or newspaper reading in the courtroom. The clerks and bailiffs also keep talking to an absolute minimum. The atmosphere is one of dignity and decorum.

Attorney applications are heard first by the judge. These are motions by attorneys either to request a continuance or to enter a settlement or to raise any other matter that may be brought before the court. Next applications by individuals, if there are any, are heard.

Following the applications, default judgments are dealt with, again first those where attorneys are involved and then where only laymen are involved. Default judgments are not automatic. Unless the defendant has been served at least seven days prior to the hearing date, no default may be entered. ${ }^{104}$ At least in actions involving personal injury or property damage, evidence of damages is supposed to be shown by sworn affidavits of experts before a default can be entered. ${ }^{105}$ Each individual or attorney appears before the judge and requests a default. In some cases the judge may inquire about the case and the amount asked. Usually in attorney cases the default seems to be granted fairly readily. Observation showed a few individual defaults in which the judge questioned the plaintiff and of these one or two resulted in a slight reduction of the award. After the award of the default the individual appearing without counsel is given a form explaining the next steps to be taken if payment of the judgment is not received. Furthermore, the court administrator must mail written notice of the entry of a default judgment to the defendant, and he may move to open or strike the judgment. ${ }^{108}$

The bulk of the cases are thus disposed of prior to the hearing of contested cases. Once again, cases in which attorneys are involved have preference, with top priority to cases where both sides are represented and secondary priority to those where only one side is represented. There is, of course, no trial by jury. ${ }^{107}$ All parties and witnesses

${ }^{104}$ Phina. Mun. CT. R. Civ. P. 115 (b).

$105 I d$. As previously mentioned, judgments by confession are barred. See note 98 supra.

106 PhIIA. Mun. CT. R. Crv. P. 115 (c), 119.

107 The right is preserved by the provision for a trial de novo in the court of common pleas. See Small Claims Court Reform, supra note 3, at 56-57; PA. Const. art. 5 $\S 16(\mathrm{r})(\mathrm{v})$ (Sched.); Capital Traction Co. v. Hof, 174 U.S. 1 (1899); cf. Smith Case, 
to contested cases to be heard are required to be sworn; ${ }^{108}$ the swearing in takes place in a mass.ceremony prior to hearing of any contested cases. Because this is a court of record, all testimony is taken down by a court reporter.

The rules of the court allow the judge to conduct the hearing "in such manner as (he) deems best suited to discover the facts and to determine the justice of the case in accordance with the Substantive Law; and shall not be bound by the formal rules of evidence, except those pertaining to privileged communications." 109 Indeed, the contested cases vary considerably in their formality and manner, depending upon differences in judges, the nature of the case, the presence or absence of attorneys, and other circumstances. The basic format follows that of a formal trial. Usually the plaintiff gives the story first and then the defendant. All the while the judge may and often does question both parties in order to get the story straight.

The judge's precise role is an ambiguous one. One judge said that if one party does not have an attorney, he looks on himself during the hearing as that party's representative. ${ }^{110}$ All the judges interviewed saw their position as chief factfinder and protector of the confused. One judge said he would consider adjourning a proceeding if one party seemed so confused that it would not be fair to continue. The two judges who were specifically asked the question were in favor of having attorneys in the court because of the ability of an attorney to sort out the facts and help in clarifying the situation.

The imprecision of the judge's role extends into the area of decision as well as conduct of the hearing. As mentioned, the rules of the municipal court require decisions to be based on substantive law. In a majority of the cases observed the theory of law underlying the decision was either loosely stated, or not stated at all. On the other hand, in some cases and with other judges, there was a heavy reliance on use of law and explanation of the legal principles relied on. One judge fell back on the rules of evidence in order to bring a case to a conclusion he felt was equitable.

One of the most interesting judicial approaches was the use of the

381 Pa. 223, 112 A.2d 625, appeal dismissed sub nom. Smith v. Wissler, 350 U.S. 858 (1955).

108 Prma. Mon. Ct. R. Civ. P. 113 (a).

109 Id. 113(b). This wording is quite similar to a typical small claims court provision. See Cayton, Small Claims and Conciliation Courts, 205 AnNaLs 57 (1939), cited in Small Claims Court Reform, supra note 3, at 55.

110 During the course of this study several different judges of the municipal court were interviewed informally. Their observations which follow in the text are not the result of a rigid interview technique, but rather resulted from a more or less free form discussion of their position. As with all those involved in this study the judges interviewed were very cooperative and seemed glad to talk about the court. 
power of the bench to exercise something that approached equity powers. This involved either postponements pending repair work or continuances while settlement was discussed. One of the judges interviewed frankly stated that he did use his position and power to reach settlements more in the manner of a court of equity. ${ }^{111}$

\section{Post-Trial}

Unlike a plaintiff in California, for example, who is deemed to have waived his right to appeal ${ }^{112}$ by electing to bring a small claims court action, either party may appeal a judgment of the Philadelphia Municipal Court for a trial de novo in the court of common pleas. ${ }^{113}$ He has thirty days to take this action. ${ }^{114}$ However, to do so, the appellant must post a $\$ 500$ bond to cover expenses and to satisfy the judgment. ${ }^{115}$ Once the appeal is perfected, the action proceeds as if it had been originally filed in the court of common pleas. ${ }^{116}$ This includes the provision requiring that claims of less than $\$ 10,000$ go to compulsory arbitration. ${ }^{117}$ As might be expected, appeals appear to be very rare.

111 One interesting power specifically granted to the judge is to permit the judgment to be paid in installments. Pa. STAT. Ann. tit. 17, \& 711.23 (Supp. 1973); Pmina. Mun. Cr. R. Crv. P. 120(b). This too is a fairly common statutory provision. Small Claims Court Reform, supra note 3, at 58.

112 CaL. Crv. Pro. CodE $\S 117$ (j) (West 1954). The validity of this one-sided right of appeal was upheld in Cook v. Superior Court, 274 Cal. App. 2d 675, 79 Cal. Rptr. 287 (1969). The theory is that plaintiff originally could have brought his action in the court of general jurisdiction. In Philadelphia, too, the jurisdiction of the Philadelphia Municipal Court over civil actions is coextensive with that of the court of common pleas. PA. Const. art. 5, $\S 16(r)(v)$ (Sched.).

113 Phita. Mun. Ct. R. Civ. P. 117; Pa. R. Civ. P. 30.

114 PA. R. CIv. P. 30.

115 Id. 30(a).

116 Id. 30(e).

117 Id. 30(f). The fairly long-standing practice of compulsory arbitration of "small" claims in the Philadelphia Court of Common Pleas is described at some length in King, Arbitration in Philadelphia and Rochester, 58 A.B.A.J. 712 (1972). See also Rosenberg \& Schubin, Trial by Lawyer: Compulsory Arbitration of Small Claims in Pennsylvania, 74 HARv. L. REv. 448 (1961). In summary, the arbitration panel consists of 3 attorneys picked from 3 lists of members of the Bar who have consented to serve. PrirA. Co. R. CoMpulsory ARB. II. One of the attorneys is appointed chairman. Id. IIC. Each panel is assigned 3 cases. Id. IID. The chairman fixes a time for the hearing of cases no less than 15 and no more than 30 days after the appointment of the panel. Id. IIIA. The hearing will be informal with the rules of evidence applying but liberally construed. Id. IIIE. Either party may request the presence of a court reporter but must pay $\$ 35.00$. Id. IIIH.

Within 20 days of the hearing the chairman will file a report and award which will have the effect of a verdict if not appealed. Id. IV. Any party may appeal the decision of the panel, but must pay all costs incurred, id. VIA2, as well as the costs of the panel as long as they do not exceed $50 \%$ of the claim, id. VIA3. The cost of the panel paid by the appealing party shall not be taxed as costs in the case and shall not be recoverable in any proceeding. $I d$. The case will be placed on the civil trial list, id. VIA1, and heard de novo, id. VIB.

The constitutionality of this compulsory arbitration was upheld in Smith Case, 381 Pa. 223, 112 A.2d 625 (1955), as not violative of either the right to trial by jury or of due process. 
After the appeal time has run, ${ }^{118}$ the enforcement of the judgment follows the procedure employed in the court of common pleas; that is to say, there are no special provisions made for the fact that only a small judgment is being satisfied. As is widely known, the procedure in collecting a judgment from an unwilling debtor is frustrating, expensive and often unrewarding. Municipal court judgments are no exception.

The first step is to obtain a praecipe for a writ of execution and file it with the prothonotary of Philadelphia County. ${ }^{119}$ The praecipe for a writ is made available by the municipal court. After the $\$ 17.00$ fee is paid to the prothonotary a writ will issue to the sheriff. ${ }^{120}$ The sheriff's office can then levy on the personal property of the defendant. ${ }^{121}$ The plaintiff must be ready to locate the personal property of the defendant to insure a successful levy. At this stage there is the problem not only of finding the defendant's property but also of making sure it is the defendant's, although the sheriff has certain powers to attach property of the defendant held by a third person. ${ }^{122}$ If the levy once made does not convince the defendant to pay, then a. sheriff's sale must be held. The actual sale of the property costs the plaintiff a minimum of another $\$ 15.00$. Under certain circumstances the defendant can be granted an extension of time before sale. ${ }^{123}$ After the sale the sheriff is allowed a small percentage of the amount realized. The plaintiff gets whatever is left up to the amount of his judgment plus interest and costs of execution. ${ }^{124}$

\section{Consumer Platntiff Cases in the Philadelphia Muntcipal Court}

An empirical study was devised to attempt to analyze in detail consumer plaintiff cases filed during 1971 in the Philadelphia Municipal Court. The perspective was to be that of the consumer plaintiff, to see how he fared both objectively and subjectively in his search for justice through the established court system. Both court records and questionnaires were used in seeking reliable empirical data on the subject.

To bring the study within manageable size, four separate months

118 No execution shall issue upon any judgment until the appeal time has expired. Phira. Mun. Cr. R. Crv. P. 118.

110 PA. R. CIv. P. 3103 (a).

120 Id. 3103(b), (e).

121 Id. 3108(a).

122 Id. 3101(b), 3108(a). Although not particularly relevant in the normal consumer plaintiff case, it might be observed that almost uniquely, Pennsylvania bars wage garnishments. PA. STAT. ANN. tit. 42, \& 886 (1966).

123 PA. R. CIV. P. 3121.

124 Id. 3136. 
were selected for concentration: March, June, September ${ }^{125}$ and December. The complete ${ }^{126}$ available court files were examined for all cases filed in each of those months, to determine which of them fell within the category of "consumer plaintiff cases." Such cases were defined as ones in which the plaintiff was an individual who brought suit against defendant for some dissatisfaction arising out of the acquisition of goods or services, including actions for the return of a leasehold security deposit.

Six hundred fourteen cases were identified during the four-month period as falling within the category of consumer plaintiff cases. While only a part of the court's business, the number of such cases brought indicated that the municipal court is more than nominally resorted to by disgruntled consumers in this area, and deserves attention as a significant consumer dispute resolution mechanism, even at the small claims level. ${ }^{127}$

At the same time, it must be appreciated that the category of cases surveyed represents only a fraction of the totality of the court's civil workload, ${ }^{128}$ not to mention the extensive criminal jurisdiction that the majority of its judges are engaged in handling. ${ }^{129}$ Table $\mathrm{A}$ presents a profile of the workload of the court. ${ }^{130}$

$125 \mathrm{~A}$ few cases filed at the beginning of October were included in the September sample.

126 The file for each case is usually quite limited, consisting primarily of the Statement of Claim, any documents filed therewith, and any documents introduced into evidence.

127 That is not to say, however, that in comparative terms this figure is particularly impressive. For example, a recent California study showed that about 325,000 small claims cases a year were filed throughout that state. The sampling in the particular court studied (the Oakland-Piedmont-Emeryville small claims court, which is in a major metropolitan center) found that slightly over $1 / 3$ of all claims filed in that court were by individuals. Not all of these, of course, were necessarily consumer plaintiff cases, but it does suggest a heavy use of the small claims court by such individuals. Moreover, at that time, the small claims court jurisdictional limit in California was only $\$ 200$. See Calif. Small Claims Court, supra note 1.

128 In addition to jurisdiction over civil claims in assumpsit and trespass, see note 70 supra, the court also hears actions for fines and penalties by any governmental agency for less than $\$ 500$, PA. STat. ANn. tit. 17, $\$ 711.3$ (Supp. 1973) and landlord eviction and rental delinquency actions, see note 72 supra. The landlord-tenant actions, although separately identified, are heard as part of the regular daily civil session of the court. Motor vehicle actions also are separately identified in the Statement of Claim. Prina. Mun. Cr. R. Crv. P. 105(b).

129 The municipal court's criminal jurisdiction extends to committing magistrates' jurisdiction, all summary offenses (other than under the motor vehicle laws), and criminal offenses with possible imprisonment of not more than 2 years ( 3 years in the case of indictable motor vehicle law violations). The judges also serve as commissioners to preside at arraignments, fix and accept bail, issue warrants, and perform duties of a similar nature. PA. Const. art. 5, § 16(r) (i)-(iii), (vi) (Sched.).

130 From the outset, the court was busy. During the first 6 months of 1969, the judges of the new municipal court conducted approximately 35,000 preliminary arraignments and hearings, heard and disposed of approximately 12,000 criminal cases and 19,000 civil cases, and the "Law Judges" were assigned more than 3,500 criminal cases within the jurisdiction of the common pleas court. Glancey v. Casey, $447 \mathrm{~Pa}$. 77, $81 \mathrm{n} .2,288$ A.2d 812, 814 n.2 (1972). 
All available data from the court records on the selected cases was extracted ${ }^{131}$ and questionnaires were then sent to each of the 614 consumer plaintiffs to attempt to acquire additional information not revealed by the court files.

\section{A. Data From Court Files}

The nature of the cases brought by consumer plaintiffs varied widely. ${ }^{132}$ The largest single category consisted of disputes arising out of home improvements and repairs, $22 \%$ of the total. The next two largest categories were complaints about an unsatisfactory product $(13 \%)$ and for the return of a rental deposit (12\%). Appliance repair and service complaints $(5 \%)$, faulty car repairs $(8 \%)$, disputes over purchase deposits not returned (7\%), and laundry and dry cleaning disputes $(5 \%)$ were also significant in number. Many cases fell into a broad miscellaneous category (18\%). ${ }^{133}$ No significant seasonal variation between the categories of cases appeared; home improvement and repair cases constituted the largest single category in all four months. Thus, a full gamut of consumer complaints found their way into the courtroom.

The nature of the defendants was more surprising. Slightly less than a third of the defendants were corporations, ${ }^{134}$ and the balance consisted of individuals, proprietorships, and partnerships. ${ }^{135}$ Moreover, an analysis of all defendants for one of the months showed no significant pattern of repetition, ${ }^{136}$ and few of the corporate defendants were large, well-known companies in the area. The reason for their absence is unclear; it may be speculated that such companies are sufficiently consumer-conscious that disputes are resolved without the necessity of litigation, or conversely perhaps consumers are reluctant to take on a "big guy."

The amount of damages asked for in the complaint indicated that

131 Although the court records are rather skimpy, see note 126 supra, a good deal of data can be extracted. Charts were prepared for each of the cases studied, showing the date of filing, the judge, final disposition, amount claimed, amount awarded, presence of attorneys (if shown), type of case, type of defendant, costs awarded (if shown), date of originally scheduled hearing, dates of all continuances, nature of documentary evidence attached to the complaint, and comments.

132 Appendix $\mathrm{B}$, Table $\mathrm{B}$, infra, contains a detailed listing.

133 Included were such items as fraudulent advertising, personal agreements not fulfilled, merchandise not delivered, and so forth.

134 See Appendix B, Table C, infra. Even this figure is probably overstated. As noted in the table, all defendants whose name included the word "company" or the like were considered corporations. In fact, some of these were probably partnerships or trade names.

135 These categories were at best imprecise. The informality of the filing procedure led to considerable imprecision in the naming of the defendants, and of course it was not always possible to tell from the record the exact nature of the defendant.

136 The survey was made for the month of June, in which there were 174 defendants. No defendant was named more than several times. 
consumer plaintiffs are prepared to bring even quite small claims into court, with the amount asked ranging over the full jurisdictional range. ${ }^{137}$ Twenty-two percent of the amounts asked were $\$ 100$ or less, and indeed $7 \%$ of these claims were for $\$ 50$ or below. Almost half of the claims (47\%) were for $\$ 200$ or less. On the other hand, a bunching of claims occurred between $\$ 491$ and $\$ 500(15 \%)$ at the jurisdictional limit. This would be as expected, inasmuch as the plaintiff is permitted to waive the amount in excess of the jurisdictional limit in order to bring the case in the municipal court. ${ }^{138}$

One of the major aims of any judicial system, of course, is the speedy rendering of justice. In this regard, the rules of the municipal court state that at the time of the filing of the statement of claims, the clerk shall set a hearing date within sixty days. ${ }^{139}$ The court records indicate that as 1971 went along, the rule became honored mainly in the breach; in June and September of that year, only nine and six cases respectively were originally scheduled for hearing within the sixty-day period. ${ }^{140}$ However, all but eight cases were scheduled within ninety days, and in the final month of the year, $31 \%$ of the cases were slated for original hearing within sixty days. Court personnel report that the trend of improvement is continuing and that they attempt to juggle judges and caseloads so that the bulk of cases at. present can be met in the sixty-day period. It should also be observed that the date of hearing may be set beyond sixty days in the first instance for the convenience of the plaintiff.

A more vexing problem can be that of continuances. The municipal court's record in this regard appears quite good, regardless of how distressing it may be to any particular plaintiff whose case is continued at the defendant's request. ${ }^{141}$ Of the 614 cases studied, only 141 , or $23 \%$, were continued even once, and only thirty-six, or $6 \%$, were continued more than once. ${ }^{142}$ Moreover, the number of continuances fell off sharply during the latter part of the year, diminishing to $12 \%$ of all cases in December, with only one case continued a second time. ${ }^{143}$

137 See Appendix B, Table D, infra.

138 PA. StaT. ANN. tit. $17, \S 711.20$ (Supp. 1972). The waiver is automatically revoked if the defendant appeals to the common pleas court.

139 Prena. Mun. Ct. R. Crv. P. 106.

140 See Appendix B, Table E-1, infra.

141 For individual plaintiffs' reactions, see the discussion of questionnaire responses at notes 205-06 infra \& accompanying text.

142 See Appendix B, Table E-2, infra.

143 Since the study only included cases disposed of, the December figures are not affected by any cases still pending. An attempt was made to determine whether significant differences existed between the various judges with regard to the granting of continuances. The number of continuances granted in fact ranged from 36 to 2 . However, the difficulty of determining the total number of cases heard by each judge and the small size of the sample precluded this information from being meaningful. 
The final disposition of the consumer plaintiff cases suggests that at least for the purpose of obtaining a formal judgment in his favor or a settlement, a trip to the municipal court may well be worth the journey for the aggrieved consumer. Of all the cases studied, over two-thirds resulted in a judgment for the plaintiff or a settlement. ${ }^{144}$ Moreover, if one excludes the cases voluntarily abandoned by the plaintiff and thus dismissed or withdrawn, ${ }^{145}$ the figure increases to just short of $90 \%$. Defaults by the defendant, although common, were by no means the rule; this occurred in less than $30 \%$ of the cases studied. Perhaps this record of plaintiff success should not be considered too surprising. For a consumer to undertake the effort of commencing and carrying through on a law suit, his motivation must be reasonably high and his sense of righteousness reasonably great. Indeed, it may be that the surprising figure is the number of contested cases in which judgment went for the defendant, slightly over $30 \%,{ }^{146}$ and this figure does not include the cases where plaintiff's claim was scaled down in awarding judgment to the plaintiff.

Although the successful plaintiff did not always get all that he asked for, his record in this regard was good. Seventy-two percent of all judgments for plaintiff were for the full amount claimed ${ }^{147}$ even if defaults are excluded, over $40 \%$ of the plaintiffs were awarded a judgment in full. ${ }^{148}$ Moreover, no tendency to "divide the difference" appeared, even in contested cases; the number of awards of exactly half the amount claimed was only $9 \%$. The size of the amount originally claimed did not seem to affect the ultimate award.

All in all, the objective record of the court, as much as it revealed, indicated that the small claims court goals of speedy and effective justice were being realized in a number of cases. However, the nature of the records did not reveal such important facts as the success of

${ }^{144}$ See Appendix B, Table F, infra.

${ }^{145} \mathrm{~A}$ number of these cases in fact resulted in a settlement. The court records show that 123 cases were dismissed and 14 cases withdrawn. See Appendix B, Table F, infra. Of the 179 questionnaires received, 27 cases were dismissed and 6 withdrawn. See Appendix $\mathrm{B}$, Table $\mathrm{J}-1$, infra. However, an analysis of the questionnaires revealed that of the 27 "dismissed cases," 17 had been settled, and of the 6 withdrawn cases, 3 had been settled. See Appendix B, Table J-2, infra. Therefore, it may be speculated that $17 / 27$ ths of the 123 cases shown of record as "dismissed" and $3 / 6$ of the 14 cases shown of record as "withdrawn" were in fact settled. This extrapolation, which increases the number of cases settled by 84 , seems a reasonable one to make in light of the close correlation between the questionnaires returned and the whole group of cases in other regards. See notes 151-65 infra \& accompanying text.

${ }^{146}$ Including cases dismissed or withdrawn as victories for the defendant, the percentage figure would be higher. But see note 145 supra.

147 See Appendix B, Table H-1, infra, which presents data based on both default and contested judgments for plaintiff. only.

148 See Appendix B, Table H-2, infra, which presents this data for contested cases 
collection. Nor, of course, did it reveal the subjective reaction of the consumer plaintiff to the procedure that he had been through. It was this sort of data and other revelant information that the questionnaire procedure was designed to seek out.

\section{B. The Questionnaire and Its Results}

The questionnaire, designed to acquire this additional information, was sent by regular mail to the addresses shown for each of the 614 consumer plaintiffs that had been identified. ${ }^{149}$ The questionnaire stated that it was being sent as part of a consumer study of the Philadelphia Municipal Court, and assured the recipient his or her name would not be used without consent. ${ }^{150}$ A self-addressed stamped envelope was enclosed for a reply. No reward or prize was offered.

One hundred seventy-nine questionnaires were returned, approximately $29 \% .^{151}$ Although a higher response had been hoped for, ${ }^{152}$ the questionnaires that were returned do represent a sizeable number of personalized consumer reactions to the courtroom experience. ${ }^{153} \mathrm{~A}$ comparison was made between cases for which questionnaires were returned and the entire pool of 614 . In three respects at least-the amount claimed, ${ }^{154}$ final disposition of record ${ }^{155}$ and attorney representation $^{156}$ - the returnees were closely similar to the larger group.

149 The clerk fills in the full name and address of both plaintiff and defendant on the statement of claim. See note 78 supra \& accompanying text.

150 The questionnaire used appears in Appendix A, infra. The content of the questionnaire was, of course, correlated to and dictated by the broader needs of the National Institute for Consumer Justice for its multicity studies. See note $\dagger$ supra.

151 Buyer vs. Seller, supra note 4, was based on 86 replies out of 153 mailings, or $56 \%$. That questionnaire was accompanied with a promise of a free copy of the 1971 Buying Guide if the questionnaire was returned, and the retail sales price of the Guide was clearly set forth as $\$ 2.65$.

152 This may be an international phenomenon. "A British committee studying consumer protection reforms was disappointed at the lack of response to committee requests for information ...." Eovaldi \& Gestrin, supra note 8, at 284 n.14.

An attempt was made to follow up unreturned questionnaires with telephone calls urging they be sent in. However, this effort was not particularly successful.

153 The questionnaire contained 31 separate questions and was 6 pages long. Although many respondents filled out the entire questionnaire, a number skipped over some of the questions asked. This will explain why the totals in a number of the tables do not add up to the total number of questionnaires returned.

154 See Appendix B, Table I, infra. Appendix B, Table D, infra, relates the amount of claim to the entire group to whom questionnaires were addressed.

155 See Appendix B, Table J-1, infra. On the strength of information supplied in the 179 questionnaires which were returned, it was possible to make a more exact determination of the disposition of those cases than was possible when relying solely on the court records. See Appendix B, Tables J-2, J-3, infra. However, for the present comparison it is appropriate to use the unadjusted figures which appear in Appendix B, Table J-1, infra. For final disposition of all 614 cases, see Appendix B, Table F, infra.

156 See Appendix $\mathrm{B}$, Table $\mathrm{K}$, infra. A bit underrepresented are plaintiffs who were represented by attorneys. Perhaps this is because the plaintiff whose case was handled by an attorney was not familiar with many of the details asked about in the questionnaire. For attorney representation in all 614 cases, see Appendix B, Table G, infra. 
There was insufficient information on cases for which no questionnaire was received to allow correlation of other variables.

\section{Income Levels}

One interesting fact at the outset that the questionnaires revealed about the use of small claims court was that contrary to some beliefs, ${ }^{157}$ a sizeable portion of the plaintiffs were people of moderate or low income. Some 37 respondents, or $25 \%$ of the total replying to the particular question, reported their family income as less than $\$ 5,000$; less than $15 \%{ }^{158}$ earned over $\$ 15,000$.

\section{Prelitigation Efforts}

Prior to going to small claims court, almost all the plaintiffs tried to settle their complaint directly with the person who sold the goods or performed the service. ${ }^{159}$ In addition, before resorting to court action, a wide range of public and private organizations were contacted for possible help, including the Better Business Bureau, the Pennsylvania Bureau of Consumer Protection, the district attorney's office, the local newspaper or television station, Community Legal Services, and Ralph Nader. Eighty-one people, almost half of the total, sought help from more than one source, and two individuals went to as many as seven different places $;^{160}$ nobody went directly to the Philadelphia Municipal Court without taking any prelitigation steps toward settlement or aid. One is led to conclude that aggrieved consumers do not have any clear notion of which public or private agency to resort to for nonjudicial help in resolving the dispute, or what course of action to follow other than complaining directly. The pattern appears to be one of considerable confusion. Of course, it may be that this simply reflects the "last-resort" nature of litigation, and that a prospective plaintiff will exhaust every possible resource before turning to the courts. On the other hand, if a particular organization had clearly established itself as the consumer's friend, one would think that a substantial percentage of the plaintiffs here would have turned to it. Such was not the case. Indeed, the course of action pursued most often, other than to complain directly, was to request a lawyer to talk

157 See, e.g., Low-Income Litigant, supra note 5, at 1662 in which it is asserted that "individual claimants in small claims courts tend to be almost entirely middle-class and well educated." The author reports that "this conclusion was drawn from interviews with judges, attorneys, and others familiar with small claims practice." Id. n.31.

158 See Appendix B, Table L, infra.

159 See Appendix B, Table M-1, infra. The 10 people answering the question who did not complain directly reported seeking 1 or more of the other types listed of prelitigation aid.

160 See id. 
to the person complained against. Fifty-seven people, or almost onethird of the total, did so. ${ }^{161}$

A related question was how the prospective plaintiff finally found out about the small claims court. This question was given on the questionnaire without a set of possible answers and therefore required a written response. Here again, it appears that the plaintiff learned about the possible judicial remedy from a variety of sources, with private lawyers $(32 \%)$ and friends or relatives (16\%) leading the list. ${ }^{162}$ Presumably, the person answering this question wrote down where he first heard about the court. ${ }^{163}$ Presumably also in many cases one or more of the sources turned to for prelitigation aid ${ }^{164}$ must have told the plaintiff about the existence of the municipal court. ${ }^{165}$ What is plain is that the existence of this mechanism for judicial relief is not a matter of common knowledge. Only a handful of people answered "I just knew" or the like.

\section{Use of Attorneys}

Unlike many small claims courts, attorneys are permitted in the Philadelphia Municipal Court. ${ }^{166}$ Indeed, preferential scheduling treatment is given cases in which attorneys do appear. ${ }^{167}$ Although no attorneys appeared for either side in over $60 \%$ of the cases studied, ${ }^{168}$ 170 plaintiffs, or $28 \%$ of the total, were represented by attorneys of record. In 22 cases, or $4 \%$, both sides were represented by attorneys, and in 53 cases, or $9 \%$, only the defendant had an attorney of record. ${ }^{169}$

How necessary or useful was it to be represented by an attorney? Certainly no plaintiff had to have one. As already described, court procedures are deliberately designed to be simple, and observation suggested that the judges were largely helpful to and considerate of plaintiffs appearing pro se. Even where the defendant was repre-

161 Eventually, 90 people received legal assistance of one sort or another. See Appendix $B$, Table $\mathrm{N}-1$, infra.

162 See Appendix B, Table M-2, infra.

163 Almost nobody listed more than 1 source of this information.

164 See Appendix B, Table M-1, infra.

165 For example, virtually every lawyer consulted would presumably have mentioned the possibility of judicial relief, even if he advised against it.

166 See text accompanying notes 67-69 supra.

167 See text accompanying notes 103-04 supra. However, if this were not done, attorney representation would be virtually out of the question because of the increase in time and resulting fees.

108 See Appendix B, Table G, infra. However, in 10 cases plaintiff was himself an attorney. Id.

169 Id. It should be noted in this regard that because no pleadings are filed by the defendant, the presence of an attorney on his side will usually appear of record only when the case comes to a hearing. Undoubtedly in some of the cases settled prior thereto, an attorney participated on the defendant's behalf. 
sented by counsel at trial, the plaintiff handling the case himself was awarded judgment in almost $70 \%$ of the cases in which the court rendered judgment, and in over half the successful cases, the plaintiff recovered judgment for at least half the amount claimed. ${ }^{170}$ These figures compare quite favorably with the sample as a whole. Of all contested cases, the plaintiff was successful in $71 \%$ and the defendant in $29 \%,{ }^{171}$ and in $60 \%$ the plaintiff recovered more than half the amount claimed. ${ }^{172}$ The conclusion from this data appears to be that if a case comes to a hearing, a plaintiff will make out about as well whether or not he is facing an attorney on the other side. No data is available on the effect which an attorney for the defendant may have in achieving favorable settlements or causing the plaintiff to drop the case. ${ }^{173}$

Did plaintiffs fare better when they were represented by counsel? The analysis of this question was based upon responses to the questionnaire. The most marked feature is that of the 36 people represented by an attorney (including plaintiffs in unlitigated cases), all but three, or $91 \%$, either obtained a judgment in their favor or settled the case, ${ }^{174}$ and it is possible that those three also were successful in settlement. ${ }^{175}$ No plaintiff represented by an attorney lost his case after a trial. ${ }^{176}$ Thus, representation by an attorney would seem to enhance the plaintiff's chances of success or at least avert a judgment for defendant. However, this conclusion must be viewed with caution. There may well be a selection process at work in that attorneys will be reluctant to take cases with little chance of success. Also, it should be observed that the number of cases settled where an attorney represented the plaintiff constituted almost $40 \%$ of the total, ${ }^{177}$ as contrasted to $28 \%$ of all those answering the questionnaire. ${ }^{178}$ This may suggest that having an attorney leads to a prompt resolution of the case out of court or that attorneys settle cases too readily. In any

170 See Appendix B, Table N-4, infra.

171 See Appendix B, Table F, infra.

172 See Appendix B, Table H-2, infra.

173 One major difficulty presented in acquiring such data is that the court records rarely show the presence of an attorney for the defendant unless the case comes to a hearing or at least is settled at the time of hearing.

174 See Appendix B, Table N-3, infra.

175 Cases withdrawn or dismissed may in fact have been favorably settled. See note accompanying Appendix B, Table J-2, infra.

176 See Appendix B, Table N-3, infra.

177 Id.

$178 \mathrm{Id}$. Of the 614 cases in the entire study, some $20 \%$ were settled of record. However, additional cases may also have been settled. If the corrective factor shown by the questionnaire is applied, this figure would increase to $33 \%$. See Appendix B, Table J-2, infra. 
event, the data suggests than an attorney will settle the case out of court for a client rather than go to court and lose.

In addition to the 36 plaintiffs formally represented by an attorney, the questionnaire showed that an even greater number, 54 people, or $32 \%$ of those answering the question, although not formally represented, had been advised by an attorney how to handle their cases themselves. ${ }^{179}$ Thus, over half of the sample, or $56 \%$, had received aid of one kind or another from an attorney or were themselves attorneys; ${ }^{180}$ only $44 \%$ handled the matter entirely on their own. Still, the $44 \%$ represents a sizeable portion of the consumer plaintiffs who used the court, and as indicated, where the plaintiff pushed on to trial, the outcome was in most instances in line with represented cases.

Nor does it appear that attorney representation was limited to well-to-do plaintiffs. Of plaintiffs formally represented, $22 \%$ had income of less than $\$ 5,000$, and $19 \%$ from $\$ 5,000$ to $\$ 10,000$. $^{181}$ Of the plaintiffs who were not formally represented but who received advice from an attorney on how to handle the case, $20 \%$ were in the former category and $26 \%$ in the latter. ${ }^{182}$ While one might expect that the community legal services assistance provided the bulk of such court aid, in fact less than half, 3 out of 8 , of the represented low-income people had CLS representation, and only 1 of the 7 in the $\$ 5,000$ $\$ 10,000$ category. ${ }^{183}$ Thirteen out of the 54 people receiving only advice obtained it from CLS, and 41 from private attorneys. ${ }^{184}$

While attorney representation was not limited to the well-to-do, the figures did reveal a disparity between low and moderate income persons in favor of the former. Thus, the relation between income and percentage of plaintiffs in that income group who were represented by an attorney is as follows: $23 \%$ of those with less than $\$ 5,000$ income, $13 \%$ of those with $\$ 5,000$ to $\$ 10,000$ income, $27 \%$ of those with $\$ 10,000$ to $\$ 15,000$ income, and $44 \%$ of those with over $\$ 15,000$ income. ${ }^{185}$ The pattern was the same for plaintiffs who received legal advice but who were not formally represented by an attorney. The -percentage of each income group receiving legal advice was as follows: $31 \%$ of those with under $\$ 5,000$ income, $25 \%$ of those with $\$ 5,000$ to $\$ 10,000$ income, $37 \%$ of those with $\$ 10,000$ to $\$ 15,000$ in-

179 See Appendix B, Table N-1, infra.

180 Four people answering the questionnaire were in this category.

181 See Appendix B, Table N-2, infra.

182 Id.

183 See note 18 accompanying Appendix $\mathrm{B}$, Table $\mathrm{N}-2$, infra.

184 See Appendix B, Table N-1, infra.

185 See Appendix B, Table $\mathrm{N}-2$, infra. 
come and $31 \%$ of those with over $\$ 15,000$ income. ${ }^{186}$ From this pattern it is possible to conclude broadly that a substantial number of low and moderate income plaintiffs were represented by the private bar. However, those with incomes under $\$ 5,000$, or low incomes, were well represented because over $35 \%$ of them had CLS assistance. ${ }^{187}$ In contrast, those plaintiffs with incomes from $\$ 5,000$ to $\$ 10,000$ were relatively underrepresented presumably because they earn too little to afford a private attorney but too much to qualify for assistance from CLS. It is probable that the same factors deter this group of plaintiffs from receiving even legal advice.

The economics of this surprisingly frequent use of attorneys is difficult to understand, in light of the low jurisdictional limit of the municipal court. In 24 of the represented cases, the plaintiff reported the amount of the fee he paid. In no instance did the fee exceed $50 \%$ of the award, and in 17 cases or $70 \%$ of the sample, the fee was less than one-quarter. Eleven of these cases involved awards of less than $\$ 200$, and 5 of them awards of less than $\$ 100{ }^{188}$ Moreover, unlike cases of plaintiff creditors, which can be handled en masse by one attorney, most of these consumer-plaintiff cases must be handled singly. Occasionally, the record or questionnaire showed that the attorney was a husband or father. Perhaps others involved friends or courtesy representation. In any event, it is plain that attorney representation does play a significant, but by no means overwhelming, part in the work of the municipal court.

\section{Collection}

Whether or not the plaintiff had an attorney, the ultimate payoff of course came in the successful collection of a judgment or settlement. The court records were largely barren of such information. One hundred eighteen questionnaires did contain an indication of the plaintiff's success or failure. Of these, $64 \%$ succeeded in collecting the amount awarded, while $36 \%$ indicated their efforts had been in vain. ${ }^{189}$ As might be expected, the significant predictive factor in the success of collection seemed to be the nature of the disposition of the case; that is, whether it was settled, won at a hearing, or won by default. While default cases represented $31 \%$ of the total of cases in the questionnaire sample resulting in the plaintiff's favor, ${ }^{190}$ they

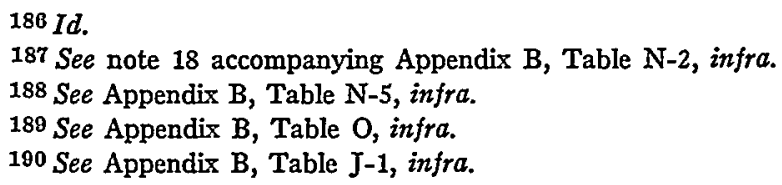


represented only $14 \%$ of the cases collected. ${ }^{191}$ Settled cases seemed the most certain of collection; of the 56 settled cases, 40 , or $70 \%$, were reported as collected; ${ }^{192}$ of the 43 cases in the sample resulting in a judgment for plaintiff after trial, ${ }^{193} 25$, or $60 \%$, were reported as collected.

Moreover, the questionnaires indicated that the surest way to collect a judgment is to do so with "no problem." Sixty of the 76 people who eventually collected, or almost $80 \%$, said they had no difficulty in doing so. ${ }^{194}$ Of the remainder, 7 said they collected through court process, 3 with their lawyer's help, and 4 by their own devices, which must have included hounding the judgment debtor. (Two people did not indicate how they collected.) Each of these, collection devices was used by some of the unsuccessful plaintiffs as well, without success. Although none of the collection devices seemed overwhelmingly successful, the use of court process did lead to success in 7 of 18 tries, almost $40 \%$, while lawyers were successful less than $15 \%$ of the time. ${ }^{195}$ The sample size, however, is not large enough to make much of this, other than to note that court process does sometimes work.

\section{Attitude Toward the Court}

Over $80 \%$ of the consumer plaintiffs who responded to the questionnaire gained either a judgment or a settlement in their favor. ${ }^{196}$ In light of this record of success, it is noteworthy that less than a majority of those answering the question, 73 out of 150 , thought that justice was done in their case, and that only 102 out of 149 would use the small claims court again. Why such dissatisfaction?

The two most obvious causes would seem to be losing the case in the first instance or, having won it, failing to collect on the judgment. Although neither of these would necessarily indicate that justice was not done-indeed it seems harsh to blame failure of collection efforts on "justice" in the abstract-the questionnaires did show that these two elements are correlated with the respondent's subjective attitude toward the court experience. Most markedly, all but one of those who thought justice was done had won or settled his case, and the one who

191 See Appendix B, Table Q, infra.

192 It is to be realized, of course, that not all the people who answered the questionnaire indicated collection success. This analysis assumes that those answering as to collection success represented a fair sample of those answering the questionnaire.

193 See Appendix B, Table J-1, infra.

194 See Appendix B, Table P, infra.

$195 I d$.

196 See Appendix B, Table J-3, infra. 
lost but yet felt justice was done stated that he sued the wrong party. Sixty-one percent of those who won their case at a contested hearing, and $76 \%$ of those who settled their cases, were satisfied that justice was done, while only $37 \%$ of those winning by default felt so. ${ }^{197}$

In part, this may reflect the psychic satisfaction of winning in a confrontation or settling, but it is undoubtedly also related to the greater collection successes in the former categories of cases. Collection success, however, is by no means correlated to satisfaction of justice as closely as the pure win-lose relationship. Of those who thought justice was done, nearly $30 \%$ had not collected on their judgment, and conversely almost a quarter of those dissatisfied with the proceedings had collected on their judgments. ${ }^{198}$

Other sources of dissatisfaction may be found in the answers to questions about court procedure, at least as subjectively perceived by the consumer plaintiff. One of the important features of a small claims court is, of course, that it be readily accessible to consumers. In addition to the question of physical location, the hours are important. As has been stated above, the Philadelphia Municipal Court has the usual workday hours in which the claim may be filed; all hearings begin at $3: 45$. Only $24 \%$ of those answering the questionnaire said they had no problem in filing the complaint. Forty-three percent went either during work $(34 \%)$ or their lunch hour $(9 \%)$. As would be expected, the hearings themselves cut into working hours in an even larger percentage of cases; fifty percent of the plaintiffs reported that their hearing occurred when they would normally be at their jobs, and only $21 \%$ said they had no problem in making the hearing. ${ }^{199}$ In light of the number of people who indicated difficulties in filing complaints and reaching the court at the appointed hour, it must be speculated that a number of prospective plaintiffs simply are unable to reach the court, particularly when centered in a single location.

If justice delayed is justice denied, so should speedy justice be measured by more than the period of time between filing and hearing. ${ }^{200}$ The questionnaires sought information on the amount of time consumed in filing the statement of claim and in waiting for the hearing on the day of trial. The process of filing the claim seemed by and large to be handled with dispatch. If both waiting time and the time required to fill out the statement of claim are taken into account, $42 \%$ of the plaintiffs completed the task in less than half an hour, and an ad-

197 See Appendix B, Table T, pt. A, infra.

108 See Appendix B, Table T, pt. I, infra.

199 See Appendix B, Table R, infra.

200 See text accompanying notes 139-43 supra. 
ditional $35 \%$ within an hour. While $23 \%$ took more than an hour, it is not possible from the data to tell whether the length of these sessions was due to waiting to see a clerk or whether it simply reflects the time required to sort through a complex claim. ${ }^{201}$ In any event, the plaintiffs gave the clerk's office high marks. Only 14 people found anything that the clerk was unable or unwilling to help with. Eighty-eight percent said that the people who worked in the court were polite.

The waiting time consumed on the day of the trial, however, was a more vexing matter. Half the plaintiffs reported waiting more than two hours, and an additional $23 \%$ said they waited about two hours. Only $7 \%$ said they waited less than one hour. ${ }^{202}$ While waiting time in court is a well-known phenomenon, there is little doubt ${ }^{203}$ that it bears adversely on the sense of justice done. Thus, of those who felt that justice was not done, $60 \%$ reported waiting more than two hours to be heard, while $46 \%$ of those satisfied with justice had waited that long. ${ }^{204}$ Moreover, while the continuance of a case per se did not affect the sense of justice, ${ }^{205}$ those who did not know about the continuance in advance were rather more apt to feel justice was not done. $^{206}$

On the other hand, once the case comes up for hearing, the time relevance is reversed. Some $47 \%$ of the cases took less than five minutes to be heard and an additional $29 \%$ less than fifteen minutes. ${ }^{207}$ On the other hand, while $60 \%$ of those who felt justice was done had a hearing of less than fifteen minutes, over $80 \%$ of those who did not feel so were summarily heard. ${ }^{208}$ Whether this reflects actual dissatisfaction with the shortness of hearing or whether it is simply influenced by the larger number of default judgment plaintiffs in the dissatisfied group may be questioned. That the latter is not the sole explanation, however, is suggested by the fact that in answer to the question whether the judge had given enough time to the plaintiff to tell completely his side of the case, almost $60 \%$ of the dissatisfied plaintiffs responded no, while only $15 \%$ of the satisfied plaintiffs did so. ${ }^{209} \mathrm{~A}$ correlative figure has to do with the answer to the question whether the judge had explained why he decided the case as he did,

201 See Appendix B, Table S-1, infra.

202 See Appendix B, Table S-2, infra.

203 It is to be hoped that the horse preceded the cart, and that the sense of injustice engendered, say, by losing the case did not distort the answer to, say, waiting times.

204 See Appendix B, Table T, pt. F, infra.

205 See Appendix B, Table T, pt. D, infra.

206 See Appendix B, Table T, pt. E, infra.

207 See Appendix B, Table S-3, infra.

208 See Appendix B, Table T, pt. G, infra.

${ }^{209}$ See Appendix B, Table T, pt. H, infra. 
rather than simply announcing who won. ${ }^{210}$ In $60 \%$ of the cases where the plaintiff was dissatisfied, the judge had not explained his decision, whereas this failure to explain had occurred in just over half of the cases where the plaintiff was satisfied. ${ }^{211}$ Curiously, although we do not attribute statistical significance to the fact, those who went to an attorney for help were slightly more dissatisfied with the quality of justice than those who did not. ${ }^{212}$

However, even though only a bare majority felt justice was done, over two out of three would use the small claims court again. In part, this may reflect the lack of any alternative; in part simply that the sense of injustice is not that strong. An analysis of the people who simply would not use the court again shows that those who lost the case at trial or obtained a default judgment make up the bulk of the group, $23 \%$ and $43 \%$ respectively.

On the other hand, the correlation with collection success and willingness to use the court again is not as great as one might expect. Fully $28 \%^{\circ}$ of those unwilling to use the court again were successful in their collection efforts. Of course, over $70 \%$ of those who failed to collect reported that they would not use the court again. ${ }^{213}$

Many of these causes of discontent revealed by the statistics reappeared when the respondents to the questionnaire were invited to write their comments and suggestions as to how they would change the court. Many different replies were received. The largest single category dealt with the time involved. Eighteen people asked for less delay and shorter waits, 12 asked that fewer cases be scheduled, 5 asked for more efficient clerks and workers, and 3 asked for more precise scheduling of cases. A second major category dealt with costs; 7 people urged lower fees. Several suggestions were made about scheduling the court at different or additional hours or days, such as Saturday. A number of people complained about the difficulty of collection; 14 people said that payment to the winner should be ensured or the court should enforce the judgment or the sheriff should be made to act faster or the like. Eleven responses expressed dissatisfaction with the ambience of the courtroom in remarks that the court should be more responsive to the people, listen better, and not treat people like cattle. Attorneys fared rather well in the written suggestions. While 4 people said attorney cases should not receive preference in hearing (probably an-

210 The practice in the Philadelphia Municipal Court is to announce the decision at the time of hearing. Only 4 people answering the questionnaire said they had to wait for a decision.

211 See Appendix B, Table T, pt. C, infra.

212 See Appendix B, Table T, pt. B, infra.

213 See Appendix B, Table U, infra. 
other reflection of the impatience with waiting time), only one person said that lawyers should be "eliminated."

\section{ConCLUSION}

The Philadelphia Municipal Court does not in several regards follow the standard pattern of true "small claims courts." The circumstances of its creation, if nothing else, would presumably preclude at least for the present any sharp departure from the relative formality of procedure. While the disgruntlement of a losing plaintiff can never be fully assuaged and there is no way to collect a judgment from a totally assetless debtor, some concern should exist about the number of consumer plaintiffs who have a subjective impression of justice denied and other complaints about the court's workings. We have in the course of this Article tried to illumine such complaints and indicate possible areas of change.

But one must not forever muse about the dark side of the moon. True, many have found the judicial remedy for consumer complaints to be frustrating and futile, ${ }^{214}$ and these may be tempted to write it off entirely as a feasible solution. It is undoubtedly the case that in a range of consumer dispute situations, judicial relief is a sterile hope, and this study indeed did not reach those who for whatever reason never made it to the courtroom door. But one plain conclusion from the study should not be beclouded. With whatever defects it may have, the Philadelphia Municipal Court has in fact produced consumer satisfaction in a significant number of consumer complaint cases. Should not then wider attention be focused on disseminating knowledge of the existence of the Philadelphia Municipal Court and how it may be used? Although no guaranteed panacea, certainly bringing an action in this court is worthy of inclusion in the array of alternatives seriously to be considered in consumer disputes, which, alas, do arise even in the City of Brotherly Love.

\section{APPENDIX 1}

THE NATIONAL INSTITUTE FOR CONSUMER JUSTICE SMALL CLAIMS COURT QUESTIONNAIRE

We need your help-to help, in turn, all American consumers. We are the National Institute for Consumer Justice. We are a non-profit organization set up to study the best methods to handle consumer

214 See, e.g., P. SCHRAG, Counsel For tHe Deceived (1972). 
problems. Our chairman is Justice Robert Braucher of the Supreme Judicial Court of Massachusetts.

One of our main goals is to find out how good small claims courts really are for the consumer. We found out through the public records that you have filed a complaint in the Philadelphia Municipal Court. Please help us by filling out and returning to us the enclosed questionnaire. Your name will not be publicly used in any manner.

We hope to send to Congress an accurate report about what consumers who actually used small claims courts thought about them. It is therefore very important to have your answers to the questionnaire. This is a chance for the American consumer to be really heard and listened to.

We know this questionnaire looks very long, but it really takes very little time to fill out. Please answer the questions as best you can. If you can't remember or don't know an answer, put "don't know." If you have any questions about the questionnaire or our organization, please telephone 594-7480. Our local address is 3400 Chestnut Street, Philadelphia, Pa. 19104.

Thank you very much for your help.

A stamped, self-addressed envelope is enclosed.

1) What was your case about?

(Refrigerator, TV set, rent, repairs, plumbing, furniture, etc.)

2) What was your complaint? In other words, why did you sue?

3) How much did you sue for? $\$$

4) If you won or settled your case, how much did you win or settle for? $\$$

5) What other ways did you try to settle your complaint before filing your complaint in small claims court? Check as many as apply. I tried to talk to or write to the person who sold me the goods or performed the service.

I wrote or called the manufacturer

I contacted the Pennsylvania Bureau of Consumer Protection

I contacted the Better Business Bureau

I wrote to Ralph Nader

I contacted the district attorney's office

I had my lawyer talk to the person I was complaining about

I contacted a local consumer organization (please name the organization

I wrote or called the consumer complaint section of a local newspaper or TV station 
_ I contacted Community Legal Services

I contacted a federal agency (please name

Other (explain

I went straight to Philadelphia Municipal Court without doing any of the above

6) If possible, please describe your experience with any of the organizations you contacted in question 5 .

7) What happened to your case? Check one answer.

After I sued, the other party offered to settle, and I accepted

- I won the case because the other party didn't show up in court

_. The judge heard the case, and I won $\$$

- The judge heard the case and I lost

- I dropped the case on my own (explain)

- The other party had the case moved to a higher court

- The other side settled the problem before we had to go to court

- Other (explain)

8) If a judge made the final decision in your case, did he say why he decided the case the way he did or did he just announce who won?

- Just announced who won

_ Explained his decision

9) If the judge decided your case, did he decide it the same day you had your trial or did you have to wait some time to find out who won?

Decided same day

I had to wait some time

10) If you lost the case, why do you think you lost?

11) Did you go to a lawyer for help with your case? Yes — No -

12) Please answer this question if you went to a lawyer. Check as many as apply.

My lawyer filed the suit

My lawyer represented me in court.

My lawyer told me how to handle the case myself

My lawyer was a Legal Aid or Community Legal Services Lawyer

Other (explain)

13) Please answer this question if you filed your case yourself.

When you went to file your claim, did the clerk help you in any way? Yes - No - 
If the clerk helped you, how did he help you?

Was there anything you asked the clerk that he could not or did not help you with (explain) Yes — No -

Were the people who worked in the court polite? Yes - No -

14) When did you go to court to file your complaint?

- Took off from work

- Went before work

Went after work

W Went during lunch break

Went during holiday or day off

— I don't work, but I had to get someone to take care of my children while I went to court

___ Going to court posed no big problem for me

Other (explain)

15) When did you go to court to appear in the trial of your case?

- Took off from work

Went before work

Went after work

Went during lunch break

-Went during holiday or day off

_ I don't work, but I had to get someone to take care of my children while I went to court

__ Going to court posed no big problem for me

Other (explain)

16) About how long did it take you to file your claim?

L Less than half hour

Less than one hour

More than one hour

Other (explain)

17) How many times was your case postponed?

18) If your case was ever postponed, did you know of this before you showed up in court? Yes - No -

19) About how long were you waiting for your case to come up the day your case went to trial?

L Less than half hour

- Less than one hour

About one hour

About two hours

More than two hours

20) About how long did the actual trial of your case take?

Less than five minutes 


\section{_ Less than fifteen minutes}

Less than half hour

More than half hour (please say about how long it took)

21) Do you feel the judge gave you enough time to tell completely your side of the case? Yes - No -

22) About what was your family income for the year 1970?

$-0-\$ 5,000$

$\longrightarrow \$ 5,000-\$ 10,000$

$\$ 10,000-\$ 15,000$

More than $\$ 15,000$

23) Please list how much it cost you to sue Court fee Attorney's fee

- Wages lost if you missed work

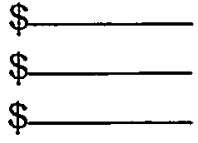
Other (babysitter, etc. explain)

$\$$

24) Did you win back any costs in court? Yes — No If so, how much? \$

25) Were you ever in small claims court before this? Yes - No If so, did you sue someone else or were you sued by someone else? I sued someone I was sued

26) Would you go to small claims court again? Yes — No -

27) How did you find out about small claims court?

28) All in all would you say justice was done in your case? Yes No -

29) If you could change the small claims court in any way, what changes would you make?

30) If you won your case or settled, did you have any trouble collecting your money? Yes — No -

31) What did you do about making the other party pay? Check as many as apply

- The other party paid me with no problem

- The court tried or is trying to collect the money for me

— A lawyer tried or is trying to collect the money for me

_ I tried or am trying to collect the money myself

— The other party disappeared

I I don't know what to do to collect the money

_- Other (explain) 


\section{APPENDIX 2}

\section{TABLES OF STATISTICS}

Table A-Profile of Civil Litigation in the Municipal Court

I. Profile of All Consumer Plaintiff Cases Studied

Table B-Type of Claim

Table C-Type of Defendant

Table D-Amount of Claim

Table E-1-Time from Filing Date to Originally Scheduled Hearing Date

Table E-2-Time from Filing Date to Final Disposition of Continued Cases

Table F-Final Disposition

Table G-Attorney Representation

Table H-1-Amount of Judgment for Plaintiff in Contested and Default Cases as Fraction of Original Claim

Table H-2-Amount of Judgment for Plaintiff in Contested Cases Only as Fraction of Original Claim

II. Profile of Cases Brought by Questionnatre Respondents Table I-Amount of Claim

Table J-1-Final Disposition as Shown by Record

Table J-2-Actual Disposition of Cases not Prosecuted by Plaintiff ("Dismissed" or "Withdrawn") As Determined from Questionnaire Responses

Table J-3-Final Disposition After Adjustment from Table J-2

Table $\mathrm{K}$-Attorney Representation of Record

\section{Analysis of Questionnaire Responses}

Table L-Income Level of Questionnaire Respondents

Table M-1-Prelitigation Use of Nonjudicial Resources

Table M-2-Source Where Plaintiff Learned of Municipal Court

Table N-1-Legal Assistance to Questionnaire Respondents

Table N-2-Incomes of Questionnaire Respondents Receiving Legal Assistance

Table N-3-Disposition of Cases Where Questionnaire Respondent Consulted Attorney

Table N-4-Disposition of Cases Where Only Defendant Represented by Attorney

Table N-5-Attorney's Fee as Fraction of Judgment or Settlement Table O-Collection Success After Judgment or Settlement 
Table P-Collection Mechanisms Tried

Table Q-Disposition of Cases Where Collection Successful

Table R-Accessibility of Court

Table S-1-Time Required to File Claim

Table S-2-Waiting Time-Day of Hearing

Table S-3-Length of Hearing

Table T-Correlation of Plaintiffs Believing Justice Was or Was Not Done with Various Factors

Table U-Correlation of Plaintiffs Who Would Not Use Court Again with Disposition of Case and Collection Success 
TABLE A

Profile of Civil Litigation in the Municipal Court

Consumer plaintiff

Consumer defendant

Code enforcement

Landlord-tenant

Other small claims ${ }^{2}$

Total

$\begin{array}{crrr}\text { Mar. }^{1} & \text { June }^{\text {1 }} & \text { Sept. } & \text { Dec. } \\ 123 & 174 & 179^{3} & 138^{4} \\ 479 & 444 & 415^{3} & 420^{4} \\ & & 2,772 & 1,542 \\ & & 751 & 445 \\ & & 2,250 & 906 \\ & & 6,307 & 3,451\end{array}$

TABLE B

Type of Clatm

Nature of Case Mar. June Sept. Dec. Total age

Home improvement and repair

Appliance repair and service

Unsatisfactory product

Faulty car repair

Rent deposit

Purchase deposit not returned

Unsatisfactory repair

Laundry and dry cleaning

Negligence-theft

Stopped check by bank

Storage and carrier

Insurance claim

Miscellaneous ${ }^{5}$

Total

$\begin{array}{llllll}27 & 34 & 45 & 31 & 137 & 22\end{array}$

$\begin{array}{rrrrrr}3 & 13 & 10 & 2 & 28 & 5 \\ 20 & 19 & 26 & 14 & 79 & 13 \\ 5 & 12 & 20 & 10 & 47 & 8 \\ 14 & 21 & 13 & 24 & 72 & 12\end{array}$

$\begin{array}{rrrrrr}9 & 18 & 8 & 10 & 45 & 7 \\ 3 & 2 & 3 & 0 & 8 & 1 \\ 8 & 10 & 9 & 5 & 32 & 5 \\ 4 & 11 & 2 & 4 & 21 & 3 \\ 0 & 2 & 1 & 0 & 3 & 1 \\ 7 & 2 & 5 & 6 & 20 & 3 \\ 6 & 0 & 3 & 2 & 11 & 2 \\ \frac{17}{123} & \frac{30}{174} & \frac{34}{179} & \frac{30}{138} & \frac{111}{614} & \frac{18}{100}\end{array}$

1 No general figures were compiled by the court for these months.

2 This is composed of suits between businesses, as well as motor vehicle cases.

3 Consumer plaintiffs were $6 \%$ of all small claims. Consumer defendants were $14 \%$ of all small claims.

4 Consumer plaintiffs were $9 \%$ of all small claims. Consumer defendants were $28 \%$ of all small claims.

5 Some of the more prominent miscellaneous claims categories were personal agreements not fulfilled (13), articles lost or damaged (7), merchandise not delivered (5), financial or mathematical error (5), and furniture held by landlord (8).

6 In all tables in this study, percentages may total slightly above or below $100 \%$ because of rounding. 
TABLE C

Type of Defendant

\begin{tabular}{lrrrrrr}
\multicolumn{1}{l}{ Type } & & & & \multicolumn{3}{c}{ Percent- } \\
$\begin{array}{lrrrrr}\text { Proprietorship and } \\
\quad \text { Individual }\end{array}$ & 85 & 99 & 121 & 98 & 403 & 66 \\
Partnership $_{\text {Corporation }}^{8}$ & 1 & 7 & 0 & 3 & 11 & 2 \\
Total & $\frac{37}{123}$ & $\frac{68}{174}$ & $\frac{58}{179}$ & $\frac{37}{138}$ & $\frac{200}{614}$ & $\frac{33}{101}$
\end{tabular}

\section{Table D}

Amount of Clatm

\begin{tabular}{|c|c|c|c|c|c|c|}
\hline Amount & & & & & & ercent \\
\hline of Claim & Mar. & June & Sept. & Dec. & Total & age \\
\hline$\$ 1-50$ & 6 & 9 & 11 & 14 & 40 & 7 \\
\hline $51-100$ & 20 & 30 & 29 & 14 & 93 & 15 \\
\hline $101-150$ & 9 & 21 & 25 & 20 & 75 & 12 \\
\hline $151-200$ & 18 & 21 & 16 & 25 & 80 & 13 \\
\hline $201-300$ & 29 & 34 & 30 & 19 & 112 & 18 \\
\hline $301-400$ & 20 & 24 & 30 & 15 & 89 & 14 \\
\hline $401-490$ & 8 & 6 & 13 & 6 & 33 & 5 \\
\hline $491-500$ & 13 & 29 & 25 & 25 & 92 & 15 \\
\hline Total & 123 & 174 & 179 & 138 & 614 & 99 \\
\hline
\end{tabular}

TABLE E-1

Time from Filing Date to Originally Scheduled Hearing Date

$\begin{array}{lrrrrr}\text { Days } & \text { Mar. } & \text { June } & \text { Sept. } & \text { Dec. } & \text { Total } \\ 1-30 & 3 & 2 & 0 & 2 & 7 \\ 31-60 & 94 & 7 & 6 & 41 & 148 \\ 61-90 & 26 & 161 & 169 & 95 & 451 \\ \text { More than } 90 & 0 & 4 & 4 & 0 & 8 \\ \text { Total } & \overline{123} & \overline{174} & \overline{179} & \overline{138} & \overline{614}\end{array}$

7 The nature of the record made it difficult or impossible to distinguish these 2 categories.

8 All defendants named as "company" or the like were included in this category. Some of them may in fact be partnerships or trade names. 
TABLE E-2

Time From Filing Date to Finat Disposition of Continued Cases ${ }^{\vartheta}$

\begin{tabular}{|c|c|c|c|c|c|c|c|c|c|c|c|c|c|c|c|c|c|}
\hline Days & & & & & & & & & & $S e_{1}$ & & & & $D e$ & & & Total \\
\hline $1-30$ & 1 & 2 & 3 & 4 & 1 & 2 & 3 & 4 & 1 & 2 & 3 & 4 & 1 & 2 & 3 & 4 & \\
\hline $31-60$ & 1 & & & & & & & & & & & & & & & & \\
\hline $61-90$ & 17 & 1 & & & 2 & & & & 3 & & & & 8 & & & & 31 \\
\hline $91-120$ & 9 & 2 & & & 20 & & & & 18 & & & & 8 & 1 & & & 58 \\
\hline $121-150$ & & 4 & & & 5 & 6 & 1 & & 11 & 2 & & & & & & & \\
\hline $151-180$ & & 1 & & & & 8 & 1 & 1 & 2 & 2 & & & & & & & 15 \\
\hline Over 180 & & 1 & 1 & & 1 & 3 & 1 & & & & & & & & & & \\
\hline Totals & 27 & 9 & 1 & 0 & 28 & 17 & 3 & 1 & 34 & 4 & 0 & 0 & 16 & 1 & 0 & 0 & 141 \\
\hline
\end{tabular}

TABLE F

Final Disposition

Result

Judgment for plaintiff

after trial

Default judgment for plaintiff

Settled

Mar. June Sept. Dec. Total age

Judgment for defendant

$\begin{array}{llllll}27 & 45 & 40 & 18 & 130 & 21\end{array}$

Dismissed

Withdrawn

Total

\begin{tabular}{|c|c|c|c|c|}
\hline 34 & 43 & 46 & 48 & 171 \\
\hline 23 & 41 & 25 & 34 & 123 \\
\hline 13 & 11 & 16 & 13 & 53 \\
\hline 25 & 32 & 46 & 20 & 123 \\
\hline 1 & 2 & 6 & 5 & 14 \\
\hline 2 & 174 & 179 & 138 & 614 \\
\hline
\end{tabular}

TABLE G ATTORNEY REPRESENTATION

Attorney

of Record

No.

Both parties ${ }^{10}$

22

Plaintiff only

148

Defendant only ${ }^{11}$

53

Percentage

4

24

Plaintiff himself

an attorney

10

Neither party

381

Total

$\overline{614}$

101

9 Shows number of times each case was continued; e.g., of cases filed in March, 1 case was continued 3 times, 9 cases twice, and 27 cases once only. For the whole, 105 cases were continued only once, 31 cases were continued twice, 4 cases were continued 3 times, and 1 case was continued 4 times.

10 Includes 14 cases where record shows both parties as represented, plus 8 litigated cases where record shows only plaintiff as represented, but defendant is a corporation. (Rules of court require that corporations be represented by an attorney.)

11 Includes 39 cases where record shows defendant was represented, plus 14 litigated cases where the defendant was a corporation. 


\section{TABLE H-1}

Amount of Judgment for Plaintiff in Contested and Default Cases as Fraction of Original Ciatm ${ }^{12}$

Amount Claimed Amount of Judgment

Less than Exactly More than Half Half . Half Full

$\begin{array}{rrrrr}\$ 1-50 & 1 & 1 & 1 & 19 \\ 51-100 & 5 & 1 & 4 & 34 \\ 101-150 & 3 & 1 & 3 & 31 \\ 151-200 & 5 & 3 & 6 & 28 \\ 201-300 & 7 & 1 & 6 & 40 \\ 301-400 & 7 & 4 & 2 & 26 \\ 401-490 & 2 & 0 & 3 & 13 \\ 491-500 & 14 & 1 & 4 & 23 \\ \text { Total } & \overline{44} & \overline{12} & \overline{29} & 214\end{array}$

\section{TABLE H-2}

Amount of Judgment for Plaintiff in Contested Cases

Only as fraction of Original Clatm

Amount Claimed

$$
\text { Less than Exactly More than }
$$

Half Half Half Full

\begin{tabular}{rr}
$\$ 1-50$ & 1 \\
$51-100$ & 3 \\
$101-150$ & 3 \\
$151-200$ & 5 \\
$201-300$ & 7 \\
$301-400$ & 6 \\
$401-490$ & 2 \\
$491-500$ & 13 \\
Total & 40 \\
\hline
\end{tabular}

Amount of Judgment Half Full

\begin{tabular}{rr}
1 & 3 \\
4 & 9 \\
3 & 7 \\
5 & 7 \\
4 & 7 \\
1 & 8 \\
2 & 6 \\
4 & 6 \\
\hline 24 & $\frac{53}{24}$
\end{tabular}

12 Totals add up to 299 and not 301 ; in 2 contested cases, the amount of the award to plaintiff was not shown. 
TABLE I

Profile of Questionnaire Responses-Amount of Cialm Amount Claimed Total Sample Questionnaire Responses

\begin{tabular}{|c|c|c|c|c|}
\hline & No. & $\begin{array}{l}\text { Percent- } \\
\text { age }\end{array}$ & No. & $\begin{array}{c}\text { Percent } \\
\text { age }\end{array}$ \\
\hline$\$ 1-50$ & 40 & 7 & 16 & 9 \\
\hline $51-100$ & 93 & 15 & 32 & 18 \\
\hline $101-150$ & 75 & 12 & 20 & 11 \\
\hline $151-200$ & 80 & 13 & 19 & 11 \\
\hline $201-300$ & 112 & 18 & 34 & 19 \\
\hline $301-400$ & 89 & 14 & 25 & 14 \\
\hline $401-490$ & 33 & 5 & 11 & 6 \\
\hline $491-500$ & 92. & 15 & 22 & 12 \\
\hline Total & 614 & 99 & 179 & 100 \\
\hline
\end{tabular}

TABLE J-1

Profile of Questionnaire Responses-

Final Disposition as Shown by Record

$\begin{array}{ccc}\text { Total Sample } & \begin{array}{c}\text { Questionnaire } \\ \text { Responses }\end{array} \\ \text { No. } & \text { Percent- } & \text { Percent- } \\ \text { age } & \text { No. } & \text { age }\end{array}$

Judgment for plaintiff

after trial

Default judgment

for plaintiff

Settled

Judgment for defendant

Dismissed

Withdrawn

Total
130

21

43

24

171

123

53

123

14

$\frac{14}{614}$

\begin{tabular}{rcr}
28 & $56^{13}$ & 31 \\
20. & 30 & 17 \\
9 & $17^{13}$ & 9 \\
20 & 27 & 15 \\
2 & 6 & 3 \\
\hline 100 & $\frac{6}{179}$ & $\frac{39}{9}$
\end{tabular}

13 Four people answered they had "lost" in court, but record showed entry of default judgment in their favor. Their cases are shown as default judgments. 


\section{TABle J-2}

Actual Disposttion of Cases Not Prosecuted BY Plaintiff ("DisMissed" OR "WithdRaWN")

As Determined from QUestionNaIre

\section{Record}

Response to

Questionnaire

"Won"14

"Lost"

"Settled"

"Dropped"

"Forgot to go"

"Other"

No response

Total
Dismissed

\begin{tabular}{rr}
2 & 0 \\
1 & 0 \\
15 & 3 \\
1 & 1 \\
1 & 0 \\
4 & 0 \\
3 & 2 \\
\hline 27 & $\frac{1}{6}$
\end{tabular}

\section{TABLE J-3}

Final Disposition After Adjustment from Table J-2

Questionnaire

Total Sample

Percent-

No.

130

age

21
Responses

No.

Percent-

age

Judgment for plaintiff

after trial

43

24

Default judgment

for plaintiff

Settled

Judgment for defendant

Dismissed

Withdrawn

Total
171

123

53

123

14

614
28

20

9

20

2

100
56

31

50

17

28

10
9

6

2

14 Since in these 2 cases, the plaintiff considered he won, it is assumed he received a favorable settlement. 
TABLE $\mathrm{K}$

Profile of Questionnatre ResponsesAtTORNEY REPRESENTATION OF RECORD ${ }^{15}$

\begin{tabular}{|c|c|c|c|c|}
\hline & \multicolumn{2}{|c|}{ Total Sample } & \multicolumn{2}{|c|}{$\begin{array}{c}\text { Questionnaire } \\
\text { Responses }\end{array}$} \\
\hline Atiorney of Record & No. & $\begin{array}{l}\text { Percent- } \\
\quad \text { age }\end{array}$ & No. & $\begin{array}{l}\text { Percent- } \\
\text { age }\end{array}$ \\
\hline parties & 22 & 4 & 4 & 2 \\
\hline atiff only & 148 & 24 & 32 & 18 \\
\hline $\begin{array}{l}\text { fendant only } \\
\text { intiff himself }\end{array}$ & 53 & 9 & 13 & 7 \\
\hline attorney & 10 & 2 & 4 & 2 \\
\hline ither party & 381 & 62 & 126 & 70 \\
\hline & 614 & 101 & 179 & 99 \\
\hline
\end{tabular}

TABLE L

INCOME LEVEL OF QUESTIONNAIRE RESPONDENTS

$\begin{array}{lcc} & \text { No. } & \text { Percentage } \\ \$ 0-5,000 & 37 & 25 \\ 5,000-10,000 & 59 & 40 \\ 10,000-15,000 & 34 & 23 \\ \text { Over } 15,000 & 19 & 13 \\ \text { Total } & \overline{149} & 101\end{array}$

15 Adjusted for 3 plaintiffs who stated in questionnaire they were themselves attorneys but were not shown as such on the record. Not recorded are 5 people answering the questionnaire who stated their attorney filed the suit for them and/or appeared in court, but the record does not so indicate. 
TABLE M-1

Prelitigation Use of Nonjudical Resources ${ }^{16}$

\begin{tabular}{lcc}
\multicolumn{1}{c}{ Type } & Using & age \\
Talked to defendant & 169 & 94 \\
Had lawyer talk to person complained about & 57 & 32 \\
Contacted the district attorney's office & 43 & 24 \\
Contacted Better Business Bureau & 37 & 21 \\
Wrote manufacturer & 33 & 18 \\
Contacted newspaper or TV & 31 & 17 \\
Contacted Community Legal Services & 30 & 17
\end{tabular}

Contacted Pennsylvania Bureau of Consumer

Protection

Contacted local consumer organization

Wrote Ralph Nader

Contacted federal agency

Other

$29 \quad 16$

$15 \quad 8$

$7 \quad 4$

$5 \quad 3$

$15 \quad 8$

No. of items checked other than "talked to defendant"

$\begin{array}{lllllll}1 & 2 & 3 & 4 & 5 & 6 & 7\end{array}$

TABLE M-2

Source Where Plaintiff Learned of Munictpal Court

Private Lawyer

No.

Friend

46

Percentage

District attorney's office

24

32

CLS/Legal Aid

14

16

"City Hall"

10

10

Radio-newspapers

10

7

Better Business Bureau

10

7

Elected representatives

Police

5

7

Consumer Reports magazine

3

Pennsylvania Consumer

Protection Agency

3

3

32

Other

\begin{tabular}{rr}
2 & 1 \\
12 & 8 \\
\hline 143 & 98
\end{tabular}

Total

2

${ }^{16}$ All respondents answered this question. As indicated above many checked a number of items. 


\section{TABLE N-1}

Legal Assistance to Questionnatre Respondents

No.

36

54

$74^{17}$

4

Did not seek advice

Plaintiff attorney himself

CLS

5

13
Private

31

41

TABLe N-2

INCOMES OF QUESTIONNAIRE RESPONDENTS ReCeIving Legal Assistance

Did Not Con-

Consulted Attorney sult Attorney ${ }^{19}$

Income

$\begin{array}{cc}\text { Advice } & \text { Represen- } \\ \text { Only } & \text { tation }^{18}\end{array}$

$\$ 0-5,000$

11

8

16

$5,000-10,000$

14

7

34

$10,000-15,000$

12

9

12

Over 15,000

5

7

4

Unknown

12

5

8

Total

54

36

74

17 Based on answer to question 11. Four people were excluded who answered question 11 "no" but in question 12 indicated that they received advice from CLS.

18 of the 5 people represented by CLS, 3 fell in the $\$ 0-5,000$ category, 1 within the $\$ 5,000-10,000$, and 1 unknown.

19 Excludes the 4 attorney plaintiffs. 


\section{TABLE N-3}

Disposition of Cases Where Questionnaire

Respondents Consulted Attorney

All

Attorney Attorney Questionnaire Advice Only Representation Respondents Percent- Percent- PercentNo. age No. age No. age

Judgment for plaintiff after trial

Judgment for

defendant

$\begin{array}{llllll}15 & 28 & 7 & 19 & 43 & 24\end{array}$

Default judgment for

plaintiff

Settled

Dismissed

Withdrawn

Total

$\begin{array}{rrrrrr}5 & 9 & 0 & 0 & 17 & 9 \\ 16 & 30 & 12 & 33 & 56 & 31 \\ 15 & 28 & 14 & 39 & 50 & 28 \\ 2 & 4 & 1 & 3 & 10 & 6 \\ 1 & 2 & 2 & 6 & 3 & \frac{2}{10} \\ \frac{2}{101} & \frac{2}{36} & \frac{100}{100} & \frac{100}{100}\end{array}$

TABLE N-4

Disposition of Cases Where Only Defendant

REPRESENTED BY ATTORNEY

\begin{tabular}{lc} 
& No. \\
Judgment for plaintiff after trial & 29 \\
Judgment for defendant & 13 \\
Default judgment for plaintiff & 0 \\
Settled & 6 \\
Dismissed & 5 \\
Withdrawn & 0 \\
Total & $\overline{53}$ \\
\hline
\end{tabular}

20 In 16 of these cases, plaintiff was awarded more than half of his claim. 
TABLE N-5

Attorney's Fee AS Fraction of JUdGMENT
OR SETTLEMENT

Amount of

Less

More

Judgment

than $1 / 4$

$1 / 4$ to $1 / 2$

than $1 / 2$

$\$ 0$

$1-50$

$51-100$

101-150

$151-200$

201-300

$301-400$

$401-490$

491-500

Total

$\begin{array}{r}1 \\ 4 \\ 2 \\ 4 \\ 3 \\ 0 \\ 1 \\ 2 \\ \hline\end{array}$

17
2

2

1

$\overline{5}$ $\overline{0}$

TABLE $O$

Collection Success After Judgment or Settlement

Collected

No.

Did not collect

Total

\begin{tabular}{lr}
$76^{21}$ & 64 \\
$42^{22}$ & 36 \\
\hline 118 & 100
\end{tabular}

Table $P$

Collection Mechanisms Tried ${ }^{23}$

No.

No problem

$60^{24}$

Court process

18

Lawyer

22

Self

14

Other

\section{Percentage}

36 


\section{TABLE $Q$}

Disposition of Cases Where Collection Was Successful No. Percentage

Judgment for plaintiff after trial

Default judgment for plaintiff

No problem

During work

Before work

After work

Lunch hour

Holiday or day off

Don't work but had to get babysitter

Other

\section{Table $R$ ACCessibility of Court}

\begin{tabular}{|c|c|c|c|}
\hline \multicolumn{2}{|c|}{ Time of Filing } & \multicolumn{2}{|c|}{ Time of Hearing } \\
\hline$N o$. & $\begin{array}{l}\text { Percent- } \\
\text { age }\end{array}$ & No. & $\begin{array}{l}\text { Percent- } \\
\text { age }\end{array}$ \\
\hline 41 & 24 & 27 & 21 \\
\hline 56 & 34 & 64 & 50 \\
\hline 8 & 5 & 4 & 3 \\
\hline 13 & 8 & 15 & 12 \\
\hline 15 & 9 & 0 & 0 \\
\hline 8 & 5 & 2 & 2 \\
\hline 13 & 8 & 9 & 7 \\
\hline 12 & 7 & 8 & 6 \\
\hline
\end{tabular}

TABLE S-1

Time Required to File Clatm No.

Less than half hour

59

Percentage

Less than 1 hour

48

42

More than 1 hour
35

23

TABLE S-2

Waiting Time-Day of Hearing

Less than half hour $\mathrm{No} .^{25}$

Less than 1 hour

2

6

About 1 hour

25

About 2 hours

29

Percentage

More than 2 hours

66 


\section{TABLE S-3}

LENGTH OF HEARING

Less than 5 minutes No.

Less than 15 minutes 54 Percentage

Less than 30 minutes

More than 30 minutes

$\begin{array}{rr}54 & 47 \\ 33 & 29 \\ 23 & 20 \\ 5 & 4\end{array}$

TABLE T

Correlation of Plaintiffs Believing Justice Was or Was Not Done With Various Factors

\begin{tabular}{lrcr}
\multicolumn{1}{c}{$\quad \begin{array}{c}\text { Part A } \\
\text { Disposition }\end{array}$} & $\begin{array}{c}\text { Justice } \\
\text { Done }\end{array}$ & $\begin{array}{c}\text { Justice } \\
\text { Not Done }\end{array}$ & $\begin{array}{c}\text { Total } \\
\text { Sample }\end{array}$ \\
$\begin{array}{l}\text { Judgment for plaintiff } \\
\text { after trial }\end{array}$ & 22 & 14 & 43 \\
Judgment for defendant & 1 & 16 & 17 \\
$\begin{array}{l}\text { Default judgment } \\
\text { for plaintiff }\end{array}$ & 18 & 31 & 56 \\
Settled & 32 & 10 & 50 \\
Dismissed & 0 & 5 & 10 \\
Withdrawn & 0 & 1 & 3 \\
Total & $\mathbf{7 3}$ & $\overline{77}$ & $\mathbf{1 7 9}$
\end{tabular}

Part B

Legal Assistance

Received attorney's aid

32

37

80

Did not receive

attorney's aid

35

34

74

Part C

Explanation by Judge

Explained decision

17

19

37

Did not explain

19

29

49

Part D

Continuances

No continuance

35

35

84

One or more

17

18

38

26 For Part A, "total sample" was taken from Table J-3. For remaining parts, the term means the total group answering the correlative question. 


\section{TABLE T Continued}

Correlation of Plaintiffs Believing Justice Was or Was Not DoNe With Various Factors

Part E

Prior Knowledge of Continuance ${ }^{27}$

Yes

No
11

7

Part F

Justice

Disposition

Waiting Time for Hearing

Less than half hour Less than 1 hour About 1 hour About 2 hours More than 2 hours
Done

1

2

10

13

22
Justice Not Done
19

25

Part G

Length of Hearing

Less than 5 minutes

Less than 15 minutes

Less than half hour

More than half hour

18

9

16

2
1

2

11

12

39
Total

Sample 26

Part H

Plaintiff Given Sufficient

Time to Tell Story?

Yes

34

22

64

No

6

32

39

\section{Part I}

Collection Success

Judgment collected

48

32

54

$18 \quad 33$

723

35

Judgment not collected

$20 \quad 28$

76

42

27 Discrepancy between $\mathrm{D}$ and $\mathrm{E}$ arises from failure of people to answer both questions or to answer them consistently. 
TABLE U

Correlation of Plaintiffs Who Would Not Use Court Again With Disposition of Case and Collection Success

Part A

Disposition of Case

No.

Judgment for plaintiff

after trial

Judgment for defendant

Default judgment

for plaintiff

Settled

Dismissed

Withdrawn

Total

\begin{tabular}{rr}
7 & 15 \\
11 & 23 \\
21 & 43 \\
4 & 9 \\
3 & 6 \\
1 & 2 \\
\hline 47 & $\frac{}{98}$
\end{tabular}

Part B

Collection Success

Collected

8

Did not collect

Total

21

100 